\title{
Late Cretaceous continental and marine vertebrate assemblages of the Laño Quarry (Basque-Cantabrian Region, Iberian Peninsula): an update
}

\author{
X. Pereda-Suberbiola ${ }^{1 *}$, J.C. Corral ${ }^{2}$, H. Astibia ${ }^{1}$, A. Badiola ${ }^{1}$, N. Bardet ${ }^{3}$, A. Berreteaga $^{1}$, E. \\ Buffetaut ${ }^{4}$, A.D. Buscalioni', H. Cappetta ${ }^{6}$, L. Cavin7, V. Díez Díaz ${ }^{1}$, E. Gheerbrant ${ }^{3}$, X. Murelaga ${ }^{1}$, \\ F. Ortega8 ${ }^{8}$ A. Pérez-García9 , F. Poyato-Ariza5, J.-C. Rage ${ }^{3}$, J.L. Sanz ${ }^{5}$, A. Torices ${ }^{8,10}$ \\ ${ }^{1}$ Universidad del País Vasco/Euskal Herriko Unibertsitatea, Facultad de Ciencia y Tecnología, Departamento de \\ Estratigrafia y Paleontología, Apartado 644, 48080 Bilbao, Spain. \\ ${ }^{2}$ Arabako Natur Zientzien Museoa/Museo de Ciencias Naturales de Álava, Siervas de Jesús, 01001 Vitoria-Gasteiz, Spain. \\ ${ }^{3}$ Sorbonne Universités, CR2P CNRS-MNHN-UPMC Paris 6, Département Histoire de la Terre, Muséum National d'Histoire \\ Naturelle, CP 38, 57 rue Cuvier, 75005 Paris, France. \\ ${ }^{4}$ CNRS UMR 8538, Laboratoire de Géologie de l'Ecole Normale Supérieure, 24 rue Lhomond, 75231 Paris Cedex 05, France. \\ ${ }^{5}$ Unidad de Paleontología, Departamento de Biología, c/Darwin 2, Universidad Autónoma de Madrid, Cantoblanco, 18049 \\ Madrid, Spain. \\ ${ }^{6}$ Institut des Sciences de l'Évolution (UM2, CNRS, IRD), Université Montpellier 2, Place Eugène Bataillon, 34095 \\ Montpellier Cedex 5, France. \\ ${ }^{7}$ Muséum d'Histoire Naturelle, CP 6434, 1211 Geneva 6, Switzerland. \\ ${ }^{8}$ Grupo de Biología Evolutiva, Facultad de Ciencias, UNED, Senda del Rey, 9, 28040 Madrid, Spain, \\ ${ }^{9}$ Centro de Geologia, Faculdade de Ciências, Universidade de Lisboa, Edificio C6, Campo Grande, 1749-016 Lisbon, Portugal. \\ ${ }^{10}$ Department of Biological Sciences, Faculty of Science, CW405 Biological Sciences Centre, University of Alberta, \\ Edmonton, Alberta, Canada T6G 2 E9.
}

\begin{abstract}
e-mail addresses: xabier.pereda@ehu.eus (X.P.-S, *corresponding author); corral.arroyo@gmail.com (J.C.C.); humberto.astibia@ehu. eus (H.A.); ainara.badiola@ehu.eus (A.Ba.); bardet@mnhn.fr (N.B.); ana.berreteaga@ehu.eus (A.Be.),eric.buffetaut@sfr.fr (E.B.); angela. delgado@uam.es (A.D.B.); henri.cappetta@univ-montp2.fr (H.C.); lionel.cavin@ville-ge.ch (L.C.); diezdiaz.veronica@gmail.com (V.D.D.); gheerbra@mnhn.fr (E.G.); xabier.murelaga@ehu.eus (X.M.); fortega@ccia.uned.es (F.O.); paleontologo@gmail.com (A.P.-G.); francisco. poyato@uam.es (F.J.P.-A.); jcrage@mnhn.fr (J.C.R.); dinoproyecto@gmail.com (J.L.S.); torices@ualberta.ca (A.T.)
\end{abstract}

Received: 23 December 2013 / Accepted: 18 December 2014 / Available online: 25 March 2015

\begin{abstract}
The vertebrate-bearing beds of the Laño quarry (Condado de Treviño) are among the most relevant sites from the Late Cretaceous of Europe. Geologically, Laño and the adjacent region are set on the southern limb of the South-Cantabrian Synclinorium (SE Basque-Cantabrian Region, northern Iberian Peninsula). The Laño sites were discovered in 1984; thousands of bones and teeth, including microfossils, have been collected during the prospection in the field and excavation campaigns. The vertebrate remains occur at two different stratigraphic horizons within a continental to shallow marine succession of Late Campanian-Maastrichtian age. The lower horizon contains the Laño 1 and Laño 2 sites, whereas the upper horizon contains the Albaina site. In the Laño sites, three fossiliferous beds (called L1A, L1B and L2) are known within an alluvial system composed mainly of fluvial sands and silts. The sedimentary structures are consistent with channel areas within an extensive braided river system. Based mainly on stratigraphic correlations, the fluvial beds of Laño are regarded as Late Campanian to Early Maastrichtian in age. These deposits have yielded a very diverse vertebrate assemblage, which consists of nearly 40 species, including actinopterygians, lissamphibians, lepidosaurs, turtles, crocodyliforms, dinosaurs, pterosaurs, and mammals. Seven genera and ten species have been erected to date in Laño. With reference to the marine vertebrate association of Albaina, it consists of at least 37 species, including sharks and rays, actinopterygians, mosasaurids, and plesiosaurs. Two genera and species of rhinobatoids (family indet.) and two new species of rhinobatids have been erected in Albaina. The fossil association indicates a Late (but not latest) Maastrichtian age. Recently, isolated turtle and dinosaur fossils have been discovered in the sublittoral beds of Albaina. The Laño quarry is one of the most noteworthy Campanian-Maastrichtian vertebrate localities of Europe by its taxonomic diversity, and provides useful information about the composition and affinities of both continental and marine vertebrate faunas from the latest Cretaceous of southwestern Europe.
\end{abstract}




\begin{abstract}
Resumen
Los niveles con fósiles de vertebrados de la cantera de Laño (Condado de Treviño) se cuentan entre los más importantes del Cretácico Superior de Europa. Desde un punto de vista geológico, Laño y la región adyacente forman parte del flanco sur del Sinclinorio Subcantábrico (SE de la Región Vasco-Cantábrica). El descubrimiento de los niveles fosilíferos remonta a 1984; las prospecciones de campo y las campañas de excavación han proporcionado miles de huesos y dientes, incluyendo microfósiles. Los restos de vertebrados aparecen en dos horizontes estratigráficos diferentes formando parte de una sucesión continental a marina litoral de edad Campaniense superior a Maastrichtiense. El horizonte inferior contiene los yacimientos de Laño 1 y Laño 2, mientras que el superior contiene solo uno: Albaina. En los yacimientos de Laño, se reconocen tres niveles fosilíferos (llamados L1A, L1B y L2) formados en el seno de un sistema aluvial compuesto por arenas y limos fluviales. Las estructuras sedimentarias indican áreas de canal dentro de un sistema trenzado muy extendido. Según las correlaciones estratigráficas, los depósitos fluviales de Laño son de edad Campaniense superior a Maastrichtiense inferior. Estos depósitos han proporcionado una asociación muy diversa de vertebrados, que consiste en cerca de 40 especies, incluyendo actinopterigios, lisanfibios, lepidosaurios, tortugas, cocodrilos, dinosaurios, pterosaurios y mamíferos. En Laño se han definido hasta el momento siete géneros y diez especies. Por lo que respecta a la asociación de vertebrados marinos de Albaina, se han reconocido al menos 37 especies, que incluyen tiburones y rayas, actinopterigios, mosasaurios y plesiosaurios. Hasta la fecha se han definido en Albaina cuatro nuevos rinobatoideos: dos especies de rinobátidos y dos géneros y especies cuya familia es indeterminada. La asociación fósil es de edad Maastrichtiense superior no terminal. Recientemente se ha descrito el hallazgo de restos fósiles aislados de tortugas y dinosaurios en los niveles marinos de Albaina. La cantera de Laño es una de las localidades de vertebrados más destacadas del Campaniense-Maastrichtiense por su diversidad taxonómica, y proporciona información relevante sobre la composición y afinidades de las faunas de vertebrados continentales y marinos del Cretácico final del suroeste de Europa.
\end{abstract}

Palabras clave: Vertebrados fósiles, biodiversidad, Campaniense-Maastrichtiense, Laño, Albaina, Península Ibérica

\section{Introduction}

The occurrence of fossil vertebrates in the Late Cretaceous of the Laño quarry is known since 1984, when the palaeontologist Xabier Orue-Etxebarria discovered bone remains in the quarry (Astibia et al., 1999a). Surface prospections along 1985 and 1986 led to the discovery of remains of turtles, crocodylians, and dinosaurs (Astibia et al., 1986, 1987; Sanz, 1986). Field research in Laño has been carried out by members of the Universidad del País Vasco/Euskal Herriko Unibertsitatea (UPV/EHU) in collaboration with researchers of the Universidad Autónoma de Madrid (UAM), the Centre National de la Recherche Scientifique (CNRS), the Université Pierre et Marie Curie (Paris VI), the Université de Montpellier II and the Museo de Ciencias Naturales de Alava/ Arabako Natur Zientzien Museoa (MCNA, Vitoria-Gasteiz). Excavations made from 1987 to 1997 yielded a very large collection of vertebrate bones and teeth, including thousands of microfossils. Many of them come from three fossiliferous levels of continental origin (L1A, L1B and L2 from the S1U3 unit of Astibia et al., 1987). Other specimens, mostly isolated teeth of marine vertebrates, have been found in two levels of an overlying unit (S2U1 of Astibia et al., 1987). Astibia et al. (1990) provided a preliminary list of the Laño vertebrates, including actinopterygians, lissamphibians, squamates, turtles, crocodyliforms, dinosaurs, pterosaurs, and mammals from the continental deposits, and selachians from the marine beds. Subsequently, a number of new vertebrate taxa have been erected on the basis of the Laño fossils, including mammals (Gheerbrant and Astibia, 1994), snakes (Rage, 1996), turtles (Lapparent de Broin and Murelaga, 1996) and crocodyliforms (Buscalioni et al., 1997). In 1999, the vertebrate associations of the Laño quarry were the subject of a monographic volume (Astibia et al., 1999b). In this work, information about the local and regional geology of the quarry and adjacent areas was given, as well as data related to the palynomorphs and taphonomy (Astibia et al., 1999b and references therein). The volume also included the systematic description of the vertebrates, including a new sauropod dinosaur from Laño (Sanz et al., 1999) and four new selachian species from Albaina (Cappetta and Corral, 1999). Other papers dealt with the petrological and geochemical features of the Laño vertebrate fossils (Elorza et al., 1999; Lécuyer et al., 2003 and Corrigendum), as well as the taphonomic features of the terrestrial and freshwater vertebrate assemblages (Pereda Suberbiola et al., 2000). Recent papers on Laño deal with the description of a new species of the mammal Lainodon (Gheerbrant and Astibia, 2012), the revision of the titanosaurian sauropod Lirainosaurus (Díez Díaz et al., 2011, 2012, 2013a, 2013b; Díez Díaz, 2013) and the dortokid turtle Dortoka (Pérez-García et al., 2012a), and the description of the theropod teeth assemblage (Torices, 2007; Torices et al., in press), among others. In the sublittoral beds of Albaina, the first dinosaur and turtle remains have recently been described (Pereda-Suberbiola et al., in press).

The aim of this paper is to give a synthetic work of the palaeontological studies made in the Laño quarry also updating the faunal list of the terrestrial and freshwater vertebrates from Laño and the marine vertebrates from Albaina.

Institutional abbreviation: MCNA, Museo de Ciencias Naturales de Álava/Arabako Natur Zientzien Museoa, VitoriaGasteiz (Spain).

\section{Geographical and geological context}

The disused quarry of Laño is located between the small villages of Laño and Albaina in the Condado de Treviño (an 


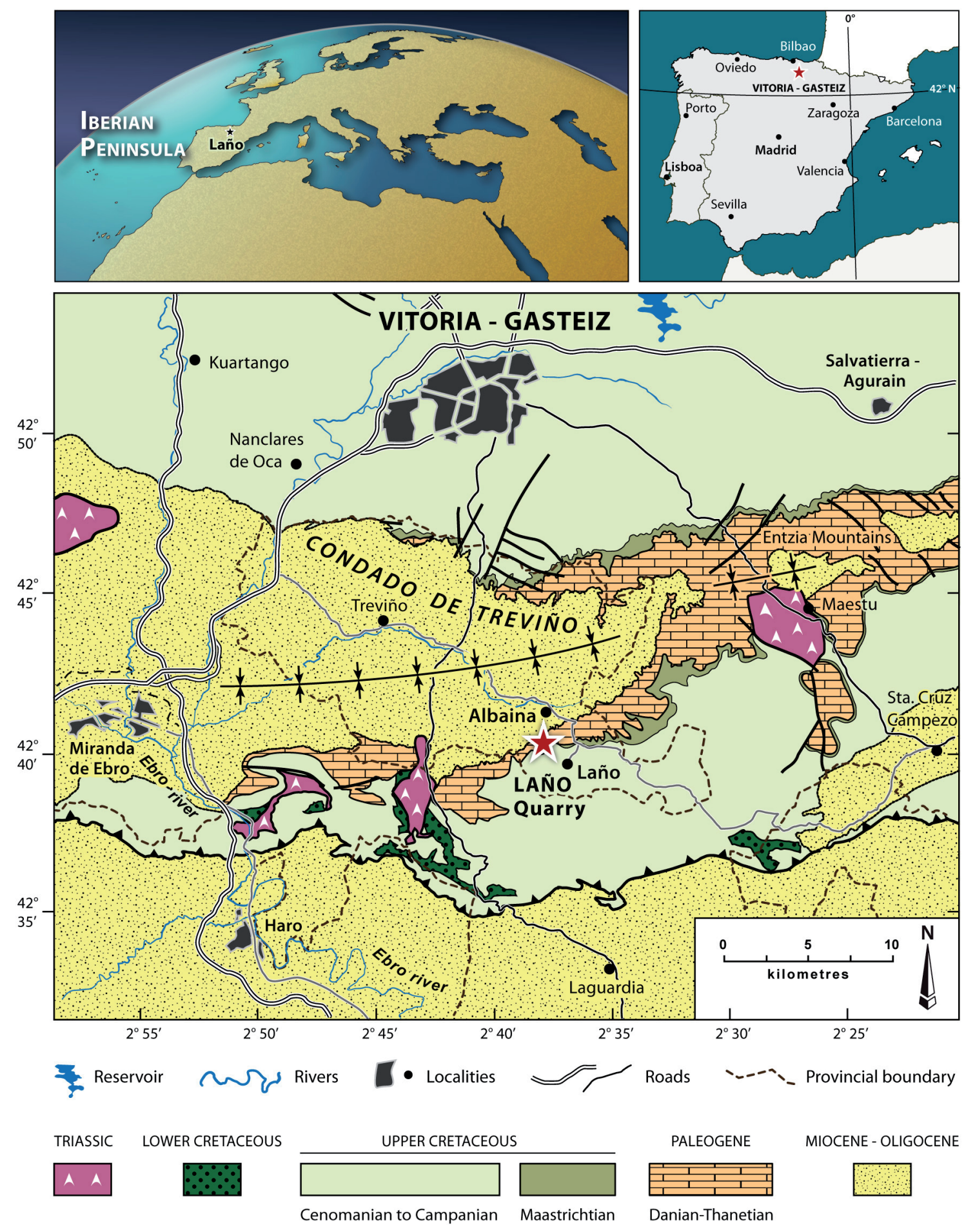

Fig. 1.- Location of the Laño quarry (Condado de Treviño) and geological sketch map (compiled and simplified geologic map from the Spanish National Geologic Map MAGNA 1:50.000).

Alava's enclave administered by the province of Burgos), about $30 \mathrm{~km}$ south the city of Vitoria-Gasteiz to the north of the Iberian Peninsula (Fig. 1).

The quarry that was largely exploited for both foundry and glass sand by Eusebio Echave S.A. (ECHASA) comprises two working faces separated by a stream (the Arroyo de Granado). In the palaeontological literature, the western working front has been referred as the Albaina site while the eastern one was named Laño site (Fig. 2). The continental fossil outcrops (Laño site) are nowadays rather overgrown and therefore collection of new specimens is more difficult with the passage of time. On the contrary, the occasional collapse of a quarry face and rockfalls in Albaina site still produce new finds, but collection must be cautiously done. As a result of 


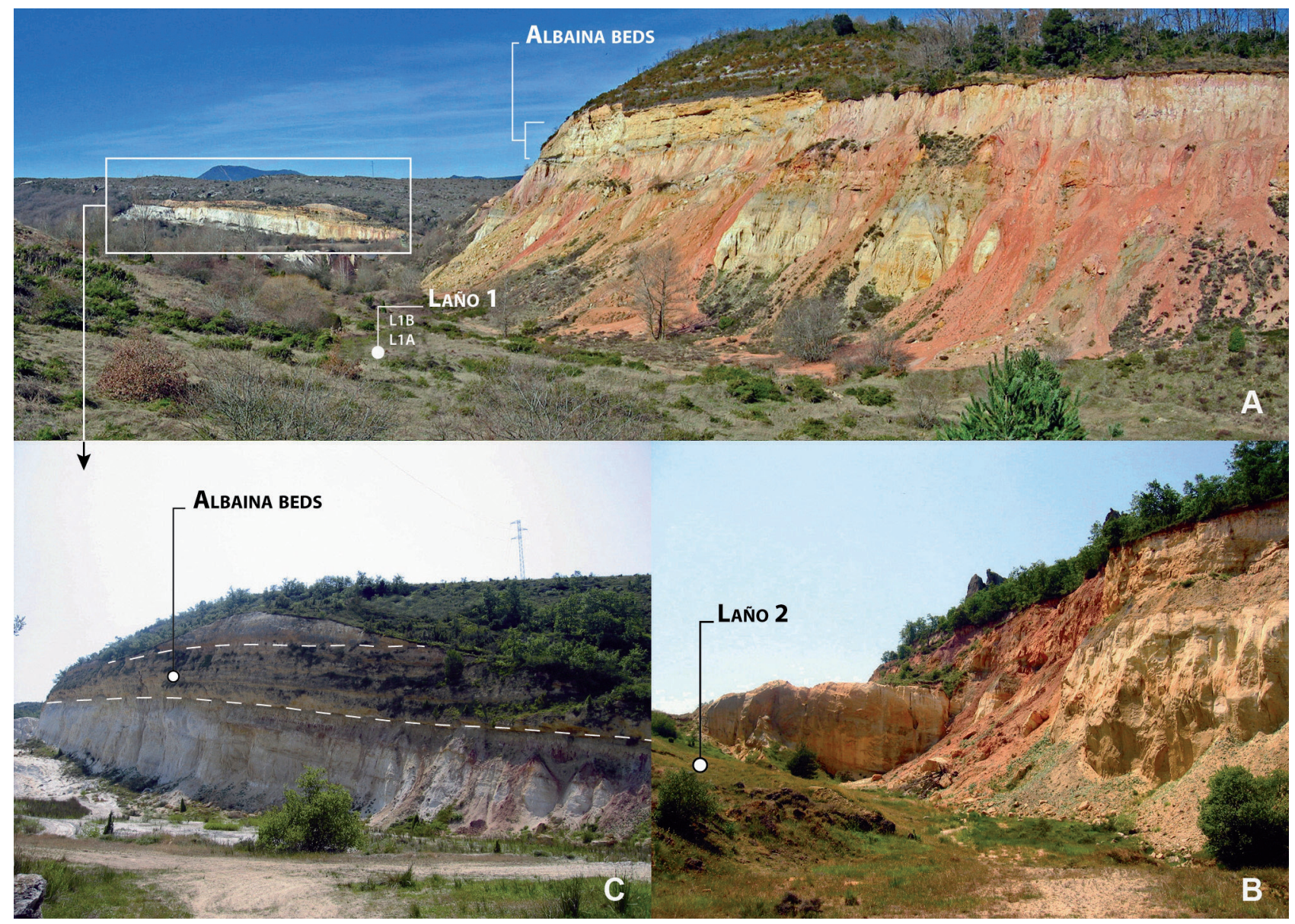

Fig. 2.- A) general view of the Laño quarry. The Laño 1 (L1A and L1B) and Albaina sites are indicated. B) Laño 2 is situated on the eastern part of the quarry. C) detail of the Albaina marine beds as seen on the western face of the Laño quarry.

the cut, a section from Late Campanian to Danian has been exposed, revealing one of the best and more diverse vertebrate fossil sites in Western Europe.

Geologically, the area lies within the southern limb of the South-Cantabrian Synclinorium, a large structure mainly composed of Upper Cretaceous and Paleogene deposits on the southeastern part of the Basque-Cantabrian Region (Baceta et al., 1999). Locally, the Laño quarry is located on the southern limb of the Miranda-Treviño syncline and includes a continental to shallow marine succession.

The Late Campanian marks a period of overall regression in the southern part of the Basque-Cantabrian Region (i.e., Navarro-Cantabrian Trough), causing land uplift, and development of fossil-rich deltaic environments and episodes of non-deposition in some marginal areas. As a result, both terrestrial and freshwater vertebrate fossils occur within an alluvial system composed mainly of fluvial sands and silts (Gómez-Alday, 1999; Pereda Suberbiola et al., 2000) in two successive beds named as L1A and L1B. Another silty fossiliferous bed named L2 occurs at the eastern end of the Laño quarry, and is apparently older in age by its correlated stratigraphic position. The sedimentary structures observed within this unit are consistent with channel areas within an exten- sive braided river system. The main fossil accumulations of Laño are associated with diagenetic ferruginous crusts, and the bones are often coated by a millimetre-sized layer of sandstone with iron-oxide matrix (Elorza et al., 1999). Based on stratigraphic correlations, these fossiliferous beds are regarded as Late Campanian to Early Maastrichtian in age (Baceta et al., 1999; lateral equivalent to the upper part of Depositional cycle DC-11 sensu Floquet, 1998; see Berreteaga, 2008) (Fig. 3).

The regressive depositional trend, exceptionally observed in the Laño-Albaina area during the Campanian and Early Maastrichtian, was later followed by transgressive sedimentation with marine strata in both limbs of the MirandaTreviño syncline. The upper part of the studied series, which reflects this episode, is chiefly consisting of over ten-metre thick marine rocks (a mixed carbonate-siliciclastic succession) cropping out in the upper levels of the quarry. Friable marine sandstones and mudstones are connected to yellow microvertebrate-rich calcarenites containing teeth and bone remains of selachians, actinopterygians, and mosasaurids by means of a lag (with occasionally vertebrate remains) that marks the cycle boundary CB-13 (sensu Floquet, 1998). This feature is clearly shown in the western part of quarry (Al- 


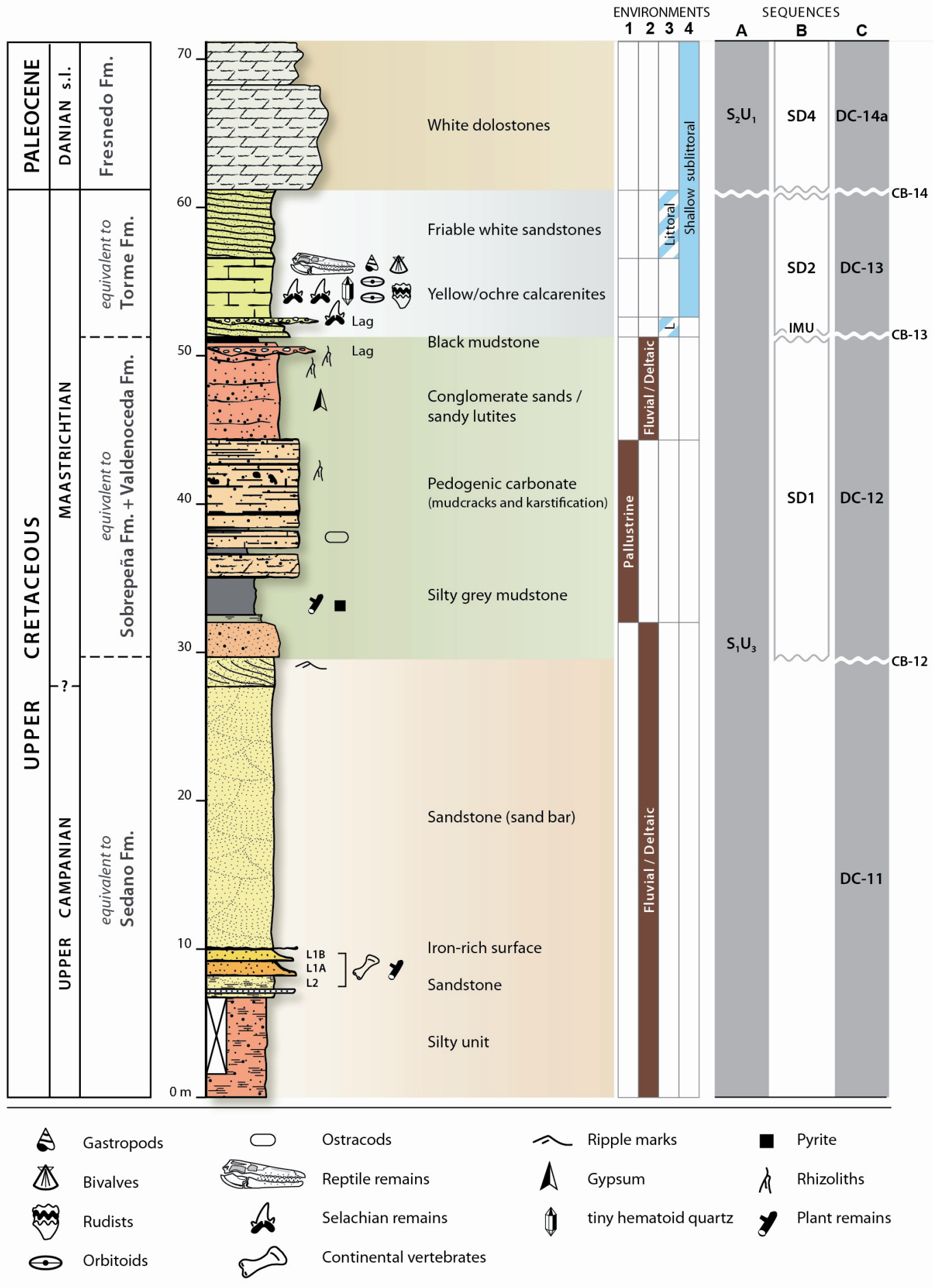

Fig. 3.- Schematic stratigraphic column of the Laño quarry showing the main lithofacies and the position of the fossiliferous levels L1A, L1B and L2 of Laño and that of Albaina (based on Astibia et al., 1999c and Berreteaga, 2008). Depositional environment: 1, Pallustrine; 2, Fluvial/Deltaic; 3, Littoral; 4, Shallow sublittoral. Sequences: A, from Astibia et al., 1987; B, from Baceta, 1996; C, from Floquet, 1998.

baina site) by means of a major intra-Maastrichtian unconformity (IMU boundary) (Baceta, 1996; Baceta et al., 1999). Invertebrate macrofossils in these calcarenites are scarce, in part because of its diagenetic history which has turned them to decalcified limestones with moldic porosity, but nevertheless layers of accumulated orbitoidids and mollusc steinkerns occur. The lack of diagnostic fossils makes difficult an ac- curate stratigraphic assignment, but according to the selachian content a Late, but not latest, Maastrichtian age is given (Cappetta and Corral, 1999). This unnamed relatively soft formation is considered to be equivalent to the DC-13 depositional cycle that was represented by the Torme Formation in the Villarcayo area of Burgos province (North-Castilian Platform; see Floquet, 1991; Berretega, 2008). The overlying 
Fresnedo Formation consists of dolomitised carbonates, easily recognized in the area as ruiniform reliefs. This lithologic succession represents a new depositional sequence DC14, bounded by cycle boundary CB-14 (sensu Floquet, 1998).

\section{Material and methods}

Fossil remains from the L1A, L1B and L2 fossiliferous levels of the Laño quarry were collected by detailed surface digging. Eight excavation campaigns were made at Laño from 1987 to 1997. During the 1995 field season, the L1A level was mapped following a metre-square grid system. Both the L1A and L1B levels were mapped during the excavations of 1997. In addition, microfossils were collected by screenwashing of the sediments from the L1A level. About 8 tons of sediments were washed. Three meshes were used during screen-washing, with wire openings of 2, 0.7 and $0.5 \mathrm{~mm}$, respectively.

Taphonomic features of the fluvial vertebrate assemblage of L1A were analyzed in order to interpret the taphonomic history of the fossil association. This analysis involved the study of a large number of variables within a well-defined sedimentological context (see Astibia et al., 1999c; Pereda Suberbiola et al., 2000). The microfossils were studied separately as they could have had a different taphonomic history.

Marine vertebrate fossils from Albaina come from the higher part of quarry face, which makes difficult direct collecting. Large isolated specimens (mostly teeth) occurred most commonly as scattered individual specimens on rock surfaces, and were directly hand-collected or by breaking off calcarenite rocks and disagregating them with a dilute solution of acetic acid. Vertebrate microfossils were obtained by screen-washing and picked up from the residue (Cappetta and Corral, 1999). Specimens were further preparated and curated at the MCNA laboratory.

The fossil vertebrate collection from the Laño quarry consists of thousands of bones and teeth, including abundant microfossils. The specimens are provisionally housed in the MCNA of Vitoria-Gasteiz (see Astibia et al., 1999b and articles therein for a detailed list of the material).

\section{Taphonomy, geochemical features of the vertebrate fossils, and palaeoecology}

The vertebrate fossil association of Laño, especially the L1A sample, is a heterogeneous assemblage of elements ranging from isolated bones and teeth to partially articulated skeletons (Astibia et al., 1999c; Pereda Suberbiola et al., 2000). The estimated body size ranges from less than $100 \mathrm{~g}$ for lissamphibians and mammals to about 3-4 tons for the largest dinosaur. The modal category of body size and weight is smaller than $1 \mathrm{~m}$ and $5 \mathrm{~kg}$, respectively. Adult individuals are much more frequent than juveniles. Several states of skeletal articulation are represented, including articulated or associated specimens in close proximity, but most of the bones are disarticulated and dispersed. Dermal bones and isolated teeth are the most common elements in the assemblage. The spatial density in the L1A level is relatively high (about 80 elements per square metre). The bones, especially the long ones, are somewhat preferentially oriented (parallel to the fluvial current), and with a variable dip. The bone distribution is non-uniform, with a relatively large coefficient of variation in bones per square metre. A large percentage of elements are broken, and two-thirds of bones are splintered. The weathering and abrasion ranges are variable according to the taxon. There is no evidence of predatory activity or chemical alteration; only fungi marks have been observed on the surface of turtle plates (Astibia et al., 1999c; Pereda Suberbiola et al., 2000).

When compared with hypothetical taphonomic examples of vertebrate accumulations (see Behrensmeyer, 1991), the features of the Laño assemblage are not compatible with flood-related monospecific mass accumulations. It looks like a fluvial attritional model of sorted remains of both small and large vertebrates. The presence of at least two modes of fossil accumulations in L1A is worthy of consideration. On one hand, the dispersed and unassociated elements were probably accumulated by the fluvial system over a large interval of time (attritional accumulation). On the other hand, the articulated and associated bones were added to the bone assemblage, probably as a result of carcasses floating into the site (Pereda Suberbiola et al., 2000). This implies that both parautochthonous and allochthonous elements (sensu Fernández López, 2000) are probably mixed together in the fossil association of Laño; palaeoecologically, there are demic elements, consisting of aquatic (bony fish, amphibians) or semi-aquatic elements (crocodyliforms, chelonians) and also ademic, terrestrial ones (solemydid turtles, dinosaurs, mammals). The dinosaur bones are commonly fractured and show a greater degree of abrasion than those of freshwater vertebrates, indicating that they may be allochthonous (Pereda Suberbiola et al., 2000). Remains of actinopterygians, amphibians, pleurodiran turtles, and eusuchian crocodyliforms are interpreted as being para-autochthonous (i.e., fluvial specific elements).

The fossil association of Laño lies between the taphonomic modes for attritional vertebrate assemblages in fluvial channels proposed by Behrensmeyer (1988). Both lithologic and taphonomic features indicate that it tends more towards the channel-fill mode than towards the channel-lag mode (Astibia et al., 1999c; Pereda Suberbiola et al., 2000). Moreover, sedimentological features observed at Laño suggest a gradual abandonment of the channel, with occasional periods of reactivation (Gómez-Alday, 1999).

Petrologically, the vertebrate fossil remains from Laño are composed of well-crystallized francolite (carbonate fluorapatite). The replacement of biogenic hydroxyapatite by francolite is related to diagenetic changes (Elorza et al., 1999). The crystallinity index of the Laño fossil bones $(\mathrm{CI}=0.2-0.3)$ is lower than that of modern bones. Compared to fresh bones, the francolite has higher concentrations of trace elements and 
rare earth elements ( $\Sigma$ REE 500 to $900 \mathrm{ppm}$ ). The geochemical composition of the Laño vertebrate fossils shows a homogeneous REE trend (Elorza et al., 1999; Lécuyer et al., 2003; Berreteaga, 2008). This suggests that the diagenetic processes were homogeneous. There is no evidence of mixing with previously diagenetically altered, reworked bones.

The diagenetic processes that lead to the Laño bone features have been interpreted as follows: 1) relatively rapid burial; 2) development of matrix and cement; 3 ) lithostatic compaction and fracturing of the bones (post-fossilization bone modification); 4) cementation of cavities and skeletal fractures (partial or total filling); 5) epidiagenesis and final fracturing (Pereda-Suberbiola et al., 1992, 2000; Elorza et al., 1999).

The main bone accumulations of Laño are associated with ferruginous surfaces. Moreover, the vertebrate remains are usually covered with nodule-like iron oxides, which are mainly composed of goethite and small detrital quartz grains with a minor percentage of clays (illite-kaolinite). The nature of the iron oxides that cover the bones is similar to that of the ferruginous structures. The development of the crusts and globule irons could have resulted from a hydromorphic process because of seasonal variations of the phreatic water (Astibia et al., 1999c; Elorza et al., 1999). This feature and the relative percentage of illite and kaolinite suggest a climate with dry and wet seasonal periods.

The stable isotope compositions of the Laño vertebrate fossils provide indirect evidence of a warm climate (subtropical to tropical) during the Campanian-Maastrichtian transition, in agreement with faunal associations (see Lécuyer et al., 2003 and Corrigendum; Berreteaga, 2008).

The small vertebrates with aquatic habits are dominant in the Laño association (Pereda Suberbiola et al., 2000). The presence of pelomedusoid turtles and crocodyliforms is consistent with an intertropical, warm climate. This interpretation agrees with the palynological assemblage found in organic matter rich beds of the alluvial system (see Fig. 3): the undergrowth was composed of ferns, gymnosperm (mainly pines and cypress) and angiosperm plants, which are indicative of a humid, temperate to subtropical climate (NúñezBetelu, 1999).

With regard to the marine assemblage of Albaina, most of the fossils are isolated teeth that occur as bioclasts in a matrix. The total number exceeds a thousand of vertebrate elements. The taphonomic factors involved in the genesis of the Albaina outcrops are not established yet; then, no attempt of palaeoecological interpretation has been done (Poyato-Ariza et al., 1999; Cappetta and Corral, 1999). The fact that in the same layer selachian teeth with a pristine conservation are found together with others showing signs of abrasion suggests that the latter remained in a nearshore energetic environment for a long time before the burial. In a few cases, teeth are so highly eroded that it is difficult to identify them. Some teeth are broken off with matrix-filled cracks because of compaction by mechanical processes. Finally, the apex of some well-preserved teeth may be splintered with sharp edges, while it is smooth-rounded in other cases; these features are probably due to damage during feeding (Cappetta and Corral, 1999).

\section{The vertebrate fossil assemblage from the continental beds of Laño}

At least 37 continental vertebrate taxa are known in the Laño 1 and 2 sites, including actinopterygians, lissamphibians, lepidosaurs, turtles, crocodyliforms, dinosaurs, pterosaurs, and mammals (see Table 1). More than half of the taxa present in the L1A association have been recognized from microfossils. Seven genera and ten species have been erected to date on the basis of the Laño material (Table 2).

\subsection{Actinopterygians}

Ray-finned fish remains from Laño include mainly ganoid scales, vertebrae and some bones and teeth. The occurrence of opisthocoelous vertebral centra indicates the presence of Lepisosteiformes, or gars, to which the ganoid scales are associated and a supracleithrum with a patch of ganoid on its external side. Cavin (1999) referred the lepisosteid remains to the genus Atractosteus on the basis of the study of Wiley (1976). A recent review of fossil and Recent Lepisosteiformes by Grande (2010) led to reevaluate osteological diagnostic characters of the group. Consequently, the Laño material is here referred to an indeterminate Lepisosteidae. Gar remains are not uncommon in the Late Cretaceous deposits of Europe, but generally not complete enough for being identified at the generic and specific level (see Cavin, 1999 and references).

Teleosteans are also present in the Laño assemblage with isolated, thin and subcircular teeth attributed to an indeterminate Phyllodontidae by Cavin (1999), but referable with caution to Phyllodus by comparison with the material from Albaina (Poyato-Ariza et al., 1999). A fragment of tooth plate was referred to ?Palaeolabrus, but this identification should be considered with extreme caution. The occurrence of Phyllodontidae and Palaeolabridae in the Late Cretaceous of Europe was first recorded in Laño (Cavin, 1999), then Phyllodontidae have been recovered in two other sites from the Maastrichtian of southern France and Spain (Laurent et al., 1999; Berreteaga et al., 2011).

\subsection{Lissamphibians}

Lissamphibian remains are relatively abundant in Laño and consist of about 200 isolated bones. The Laño assemblage is one of the richest and most diverse among those from the Late Cretaceous of Europe (Duffaud and Rage, 1999; Duffaud, 2000; Folie and Codrea, 2005). Unfortunately, the available material does not enable identification below the family level. The Laño association comprises at least five taxa: one indeterminate albanerpetontid Allocaudata (represented by 


\begin{tabular}{|c|c|c|c|c|c|c|c|}
\hline & L1A & L1B & $\mathrm{L} 2$ & & L1A & L1B & $\mathrm{L} 2$ \\
\hline Osteichthyes & & & & Crocodyliformes & & & \\
\hline Actinopterygii & & & & Neosuchia & & & \\
\hline Ginglymodi & & & & ?Ischyrochampsa sp. & $\mathrm{X}$ & & $\mathrm{X}$ \\
\hline Lepisosteiformes & & & & Eusuchia & & & \\
\hline Lepisosteidae & & & & Allodaposuchus sp. & $\mathrm{X}$ & & \\
\hline Lepisosteidae indet. & $\mathrm{X}$ & $\mathrm{X}$ & & ?Alligatoroidea & & & \\
\hline Teleostei & & & & Acynodon iberoccitanus & $\mathrm{X}$ & $\mathrm{X}$ & $\mathrm{X}$ \\
\hline Elopiformes & & & & Musturzabalsuchus buffetauti & $\mathrm{X}$ & $\mathrm{X}$ & $\mathrm{X}$ \\
\hline Phyllodontidae indet. & $\mathrm{X}$ & & & Dinosauria & & & \\
\hline Palaeolabridae & & & & Saurischia & & & \\
\hline ?Palaeolabrus sp. & $\mathrm{X}$ & & & Theropoda & & & \\
\hline Lissamphibia & & & & Neoceratosauria & & & \\
\hline Allocaudata & & & & Abelisauroidea & & & \\
\hline Albanerpetonidae indet. & $\mathrm{X}$ & & & cf. Tarascosaurus sp. & $\mathrm{X}$ & $\mathrm{X}$ & \\
\hline Caudata & & & & Tetanurae & & & \\
\hline Salamandridae indet. & $\mathrm{X}$ & & & Coelurosauria & & & \\
\hline Anura & & & & Coelurosauria indet. & $\mathrm{X}$ & & \\
\hline Discoglossidae indet. & $\mathrm{X}$ & & & cf. Richardoestesia sp. & $\mathrm{X}$ & & \\
\hline Palaeobatrachidae indet. & $\mathrm{X}$ & & & Maniraptora & & & \\
\hline Anura indet. (one or several species) & $\mathrm{X}$ & & & Maniraptora indet. & $\mathrm{X}$ & & \\
\hline Lepidosauria & & & & Paraves & & & \\
\hline Squamata & & & & Paraves indet. & $\mathrm{X}$ & & \\
\hline Lacertilia & & & & Dromaeosauridae & & & \\
\hline Iguanidae indet. & $\mathrm{X}$ & & & cf. Pyroraptor olympus & $\mathrm{X}$ & & \\
\hline Scincomorpha indet. & $\mathrm{X}$ & & & cf. Dromaeosauridae indet. & $\mathrm{X}$ & & \\
\hline Lacertilia indet. (3 species) & $\mathrm{X}$ & & & Sauropoda & & & \\
\hline Amphisbaenia or Anguidae indet. & $\mathrm{X}$ & & & Titanosauria & & & \\
\hline Serpentes & & & & Lirainosaurus astibiae & $\mathrm{X}$ & $\mathrm{X}$ & $\mathrm{X}$ \\
\hline Madtsoidae & & & & Ornithischia & & & \\
\hline Menarana laurasiae & $\mathrm{X}$ & $\mathrm{X}$ & $\mathrm{X}$ & Ornithopoda & & & \\
\hline Herensugea caristiorum & $\mathrm{X}$ & & & Ornithopoda indet. & $\mathrm{X}$ & & \\
\hline ?Sphenodontia & & & & Rhabdodon sp. & $\mathrm{X}$ & $\mathrm{X}$ & $\mathrm{X}$ \\
\hline ?Eilenodontinae indet. & $\mathrm{X}$ ? & & & Hadrosauroidea indet. & $\mathrm{X}$ & & \\
\hline Testudinata & & & & Thyreophora & & & \\
\hline Stem Testudines & & & & Ankylosauria & & & \\
\hline Solemydidae & & & & Nodosauridae & & & \\
\hline Solemys vermiculata & $\mathrm{X}$ & $\mathrm{X}$ & & Struthiosaurus sp. & $\mathrm{X}$ & $\mathrm{X}$ & $\mathrm{X}$ \\
\hline Testudines & & & & Pterosauria & & & \\
\hline Pan-Pleurodira & & & & Pterodactyloidea & & & \\
\hline Dortokidae & & & & Azhdarchidae & & & \\
\hline Dortoka vasconica & $\mathrm{X}$ & $\mathrm{X}$ & & Azhdarchidae indet. & $\mathrm{X}$ & $\mathrm{X}$ & \\
\hline Pelomedusoides & & & & Mammalia & & & \\
\hline Bothremydidae & & & & Eutheria & & & \\
\hline Polysternon atlanticum & $\mathrm{X}$ & & $\mathrm{X}$ & Zhelestidae & & & \\
\hline \multirow[t]{3}{*}{ Bothremydidae indet. } & & & $\mathrm{X}$ & Lainodon orueetxebarriai & $\mathrm{X}$ & & \\
\hline & & & & Lainodon ragei & $\mathrm{X}$ & & \\
\hline & & & & Lainodon sp. & $\mathrm{X}$ & & \\
\hline
\end{tabular}

Table 1. Updated list of continental vertebrates from Laño (Late Campanian-Early Maastrichtian).

incomplete dentaries, axis, and fragmentary humeri), one indeterminate Caudata (atlas, trunk vertebrae, humerus), and at least three anurans: one indeterminate Discoglossidae (maxillaries, angulars, vertebrae, urostyle, humeri, and ilia), one indeterminate Palaeobatrachidae (angulars, presacral vertebra, synsacrums, humeri, and ilia), and at least one indeterminate anuran (maxillaries, humeri and ilia that could belong to one or several species) (Duffaud and Rage, 1999; Duffaud, 2000). The palaeobatrachid remains are dominant relative to other taxa (about $70 \%$ of the lissamphibian assemblage). Interestingly, Laño has yielded one of the oldest Salamandridae (Duffaud and Rage, 1999; Duffaud, 2000). Moreover, the palaeobatrachid of Laño ranks among the oldest doubtless representatives of the family (Duffaud, 2000; Wuttke et al., 2012).

\subsection{Lepidosaurs}

Although the squamate remains from Laño are not really numerous (about 50 specimens), the assemblage is one of the richest and most diverse from the Late Cretaceous of Europe (Rage, 1999; Folie and Codrea, 2005). Laño has produced at least eight species: six "lacertilians" (a group that is considered to be paraphyletic) and two madtsoiid snakes still known only from Laño: Madtsoia laurasiae and Herensugea caristiorum (Rage, 1996, 1999). Recently, M. laurasiae has been removed from Madtsoia to Menarana, a genus known elsewhere only from the Maastrichtian of Madagascar (LaDuke et al., 2010).

"Lacertilians" of Laño include a non-acrodontan iguanian, i.e. Iguanidae sensu lato (represented by maxillary and oth- 


\begin{tabular}{|c|c|c|}
\hline HIGHER TAXA & GENERA & SPECIES \\
\hline \multicolumn{3}{|c|}{ LAÑO (continental unit, Late Campanian to Early Maastrichtian) } \\
\hline \multicolumn{3}{|c|}{ Turtles } \\
\hline \multirow[t]{2}{*}{ Dortokidae Lapparent de Broin and Murelaga, 1996} & Dortoka Lapparent de Broin and Murelaga, 1996 & Dortoka vasconica Lapparent de Broin and Murelaga, 1996 \\
\hline & & Polysternon atlanticum Lapparent de Broin and Murelaga, 1996 \\
\hline Solemydidae Lapparent de Broin and Murelaga, 1996 & Solemys Lapparent de Broin and Murelaga, 1996 & Solemys vermiculata Lapparent de Broin and Murelaga, 1996 \\
\hline \multicolumn{3}{|l|}{ Snakes } \\
\hline & Herensugea Rage, 1996 & Herensugea caristiorum Rage, 1996 \\
\hline & & Menarana laurasiae (Rage, 1996) \\
\hline \multicolumn{3}{|l|}{ Crocodylians } \\
\hline & Acynodon Buscalioni, Ortega and Vasse, 1997 & Acynodon iberoccitanus Buscalioni, Ortega and Vasse, 1997 \\
\hline & Musturzabalsuchus Buscalioni, Ortega and Vasse, 1997 & Musturzabalsuchus buffetauti Buscalioni, Ortega and Vasse, 1997 \\
\hline \multicolumn{3}{|l|}{ Dinosaurs } \\
\hline & $\begin{array}{l}\text { Lirainosaurus Sanz, Powell, Le Loeuff, Martínez and } \\
\quad \text { Pereda Suberbiola, } 1999\end{array}$ & $\begin{array}{l}\text { Lirainosaurus astibiae Sanz, Powell, Le Loeuff, Martínez and } \\
\quad \text { Pereda Suberbiola, } 1999\end{array}$ \\
\hline \multicolumn{3}{|l|}{ Mammals } \\
\hline \multirow[t]{2}{*}{ Lainodontinae Gheerbrant and Astibia, 2012} & Lainodon Gheerbrant and Astibia, 1994 & Lainodon orueetxebarriai Gheerbrant and Astibia, 1994 \\
\hline & & Lainodon ragei Gheerbrant and Astibia, 2012 \\
\hline \multicolumn{3}{|l|}{ ALBAINA (marine unit, Late Maastrichtian) } \\
\hline \multicolumn{3}{|l|}{ Rays } \\
\hline & Ataktobatis Cappetta and Corral, 1999 & Ataktobatis variabilis Cappetta and Corral, 1999 \\
\hline & Vascobatis Cappetta and Corral, 1999 & Vascobatis albaitensis Cappetta and Corral, 1999 \\
\hline & & Rhinobatos echavei Cappetta and Corral, 1999 \\
\hline & & Rhinobatos ibericus Cappetta and Corral, 1999 \\
\hline
\end{tabular}

Table 2. List of vertebrate taxa erected on the basis of material found in the Late Cretaceous of the Laño quarry.

er fragments with teeth), an indeterminate scincomorphan (maxillary or dentary fragments with teeth) and at least three other indeterminate species (based on isolated teeth) (Rage, 1999). One isolated tooth may belong to Paramacellodidae, a group of scincomorphans known in the Late Cretaceous of Europe (Folie and Codrea, 2005). Laño was the first locality to document the presence of Iguanidae s.l. in the Cretaceous of Europe (Rage, 1999). Several vertebrae from Laño have tentatively been referred to Amphisbaenia (Astibia et al., 1990). If the identification is correct, it is the oldest representative of this group in Europe. Nevertheless, this assignment remains uncertain as a referral to Anguidae cannot be ruled out. Then, it would be the oldest anguid recorded in Europe (Rage, 1999; Blain et al., 2010; Augé, 2012).

Several isolated vertebrae from Laño have been referred to indeterminate lacertilians (Rage, 1999). Two of them display a peculiar morphology, with a pachyostotic centrum and zygosphene-zygantrum articulations. This material may belong to a non-ophidian pythonomorph (i.e., varanoid; A. Houssaye, pers. comm.).

Snakes represent about half of the squamate remains from Laño. The two madtsoiid taxa known in the locality (Fig. 4) rank among the very rare members of this Gondwanan family in the Laurasian continents (Rage, 1996; LaDuke et al., 2010; Vasile et al., 2013). Menarana laurasiae is a large snake (estimated length $2.5 \mathrm{~m}, 7 \mathrm{~cm}$ in mid-body diameter; see LaDuke et al., 2010). Herensugea caristiorum is smaller in size (approximately $1 \mathrm{~m}$ in total length). It was probably a fossorial or secretive form (Rage, 1999). Finally, there is no evidence of "aniliid" snakes at Laño. The preliminary identification of Aniliidae (Astibia et al., 1990) was based on fragmentary vertebrae that actually belong to the madtsoiid Herensugea (Rage, 1999).

Recently, Apesteguía (2012) has suggested the presence of an eilenodontine sphenodontian in Laño on the basis of a fragmentary maxilla or dentary with acrodont dentition. However, the original description of this piece considered the tooth attachment as being pleurodont, so it was referred to an indeterminate lacertilian (Rage, 1999: Fig. 5).

\subsection{Turtles}

Turtle bones are the most dominant elements in the macrofossil assemblage of Laño. More than a thousand specimens have been found in Laño. Most of them correspond to disjointed plates and fragments of plates. However, some partial fragments of shells as well as isolated vertebrae and pelvic bones have also been collected (Lapparent de Broin and Murelaga, 1999). More than a hundred individuals are probably represented in the assemblage. The Laño turtles are currently attributed to three different species (Fig. 5). One of them is the solemydid Solemys vermiculata (stem Testudines). The other two taxa are members of Pan-Pleurodira: the dortokid Dortoka vasconica and the bothremydid Polysternon atlanticum (Lapparent de Broin and Murelaga, 1996, 1999; Pérez-García, 2009, 2012).

Nearly half of the turtle specimens found in Laño belong to Dortoka vasconica. It is the smallest turtle taxon recognized in the site, the estimated maximum length of the adults in the site, the estimated maximum length of the adults being less than $20 \mathrm{~cm}$. Dortoka vasconica is characterized by the presence of a medial strong ornamentation of tubercles and 
A

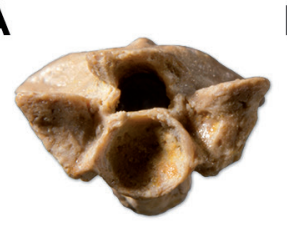

B

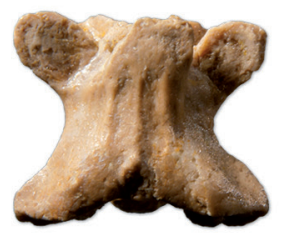

C

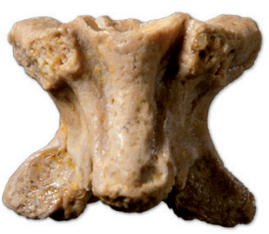

$5 \mathrm{~mm}$
D

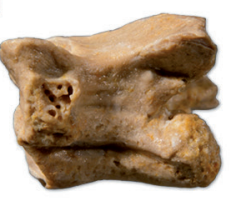

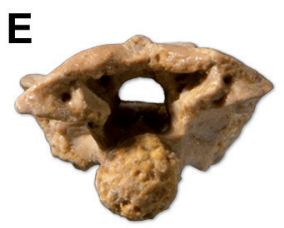

H
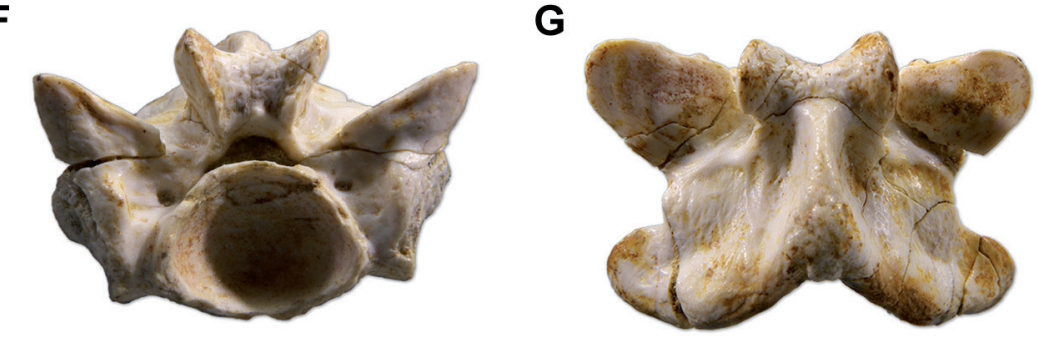

\section{G}
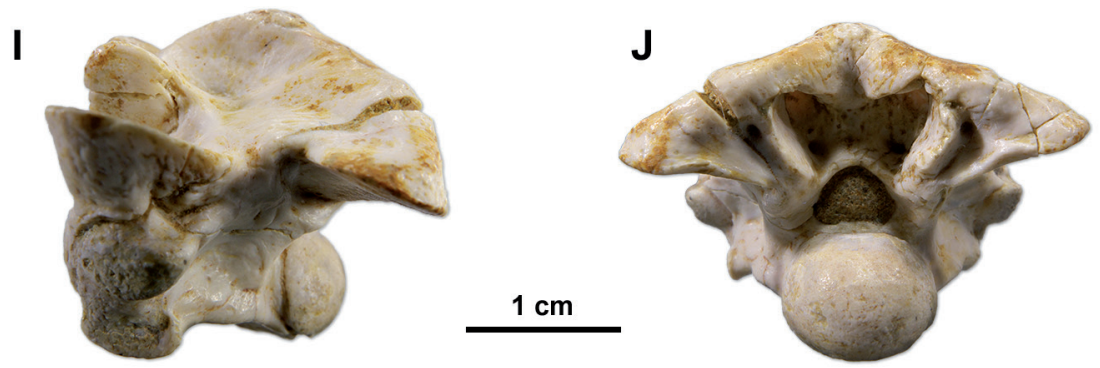

Fig. 4.- Madtsoiid snakes defined in Laño. A-E, Herensugea caristiorum Rage, 1996: MCNA 5387, mid-trunk vertebra in anterior, dorsal, ventral, lateral and posterior views; F-J, Menarana laurasiae (Rage, 1996): MCNA 5337, mid-trunk vertebra in anterior, dorsal, ventral, lateral and posterior views.

minute pits, crests and ridges on the neurals and the medial region of the costal plates (Lapparent de Broin et al., 2004). The presence of a pair of large, persistent fontanelles on its carapace, with an autapomorphic configuration, together with its highly vascularised bone histology, indicates that it was an aquatic freshwater turtle (Fig. 5E; Pérez-García et al., 2012a). Dortoka is a representative of Dortokidae, an endemic European lineage of Pan-Pleurodira. Due to the absence of cranial material, its systematic position is a debated topic. Dortokids are generally considered as the sister taxon of Eupleurodira or the sister taxon of Pelomedusoides (Lapparent de Broin and Murelaga, 1999; Gaffney et al., 2006).

Bothremydids are the most abundant and diverse group of turtles from the Late Cretaceous of southern Europe (Lapparent de Broin and Murelaga, 1999; Gaffney et al., 2006; Pérez-García et al., 2012b, 2013). The carapace of Polysternon atlanticum (up to $32 \mathrm{~cm}$ long) is smaller than that of the other known species of this genus, Polysternon provinciale. Its outer surface shows "pelomedusoid ornamentation", composed of small dichotomous discontinuous grooves that may anastomose forming small and almost flat polygons (Lapparent de Broin and Murelaga, 1999). Polysternon is identified as a member of Foxemydina, a group to which belong all the bothremydids identified in the Cretaceous of Europe (Elochelys, Polysternon, Foxemys, Iberoccitane- mys), except the Portuguese taxon Rosasia (Gaffney et al., 2006; Pérez-García et al., 2013). It has been interpreted that Polysternon probably lived in the deepest aquatic part of the fluvial environment of Laño (Lapparent de Broin and Murelaga, 1999).

Solemys vermiculata is the largest turtle in Laño: in the larger known adults, the length of the carapace reach about $70 \mathrm{~cm}$. Solemys is decorated by granulations, close or separated, and by vermiculations (Lapparent de Broin and Murelaga, 1999). The study of both cranial and postcranial material of Solemydidae allows its identification as belonging to the stem group of Testudines (Joyce et al., 2011; Anquetin, 2012). The presence of osteoderms, known in the limbs of several representatives of Solemydidae, suggests terrestrial habitat (Lapparent de Broin and Murelaga, 1999; Joyce et al., 2011). This hypothesis has recently been confirmed by histological studies (Scheyer et al., 2015)

\subsection{Crocodyliforms}

Crocodyliform remains are abundant in Laño. Both cranial and postcranial bones have been found, most of them as disarticulated elements. Isolated teeth are by far the most abundant, including several hundred of specimens from smaller and larger individuals. On the basis of isolated skull bones 

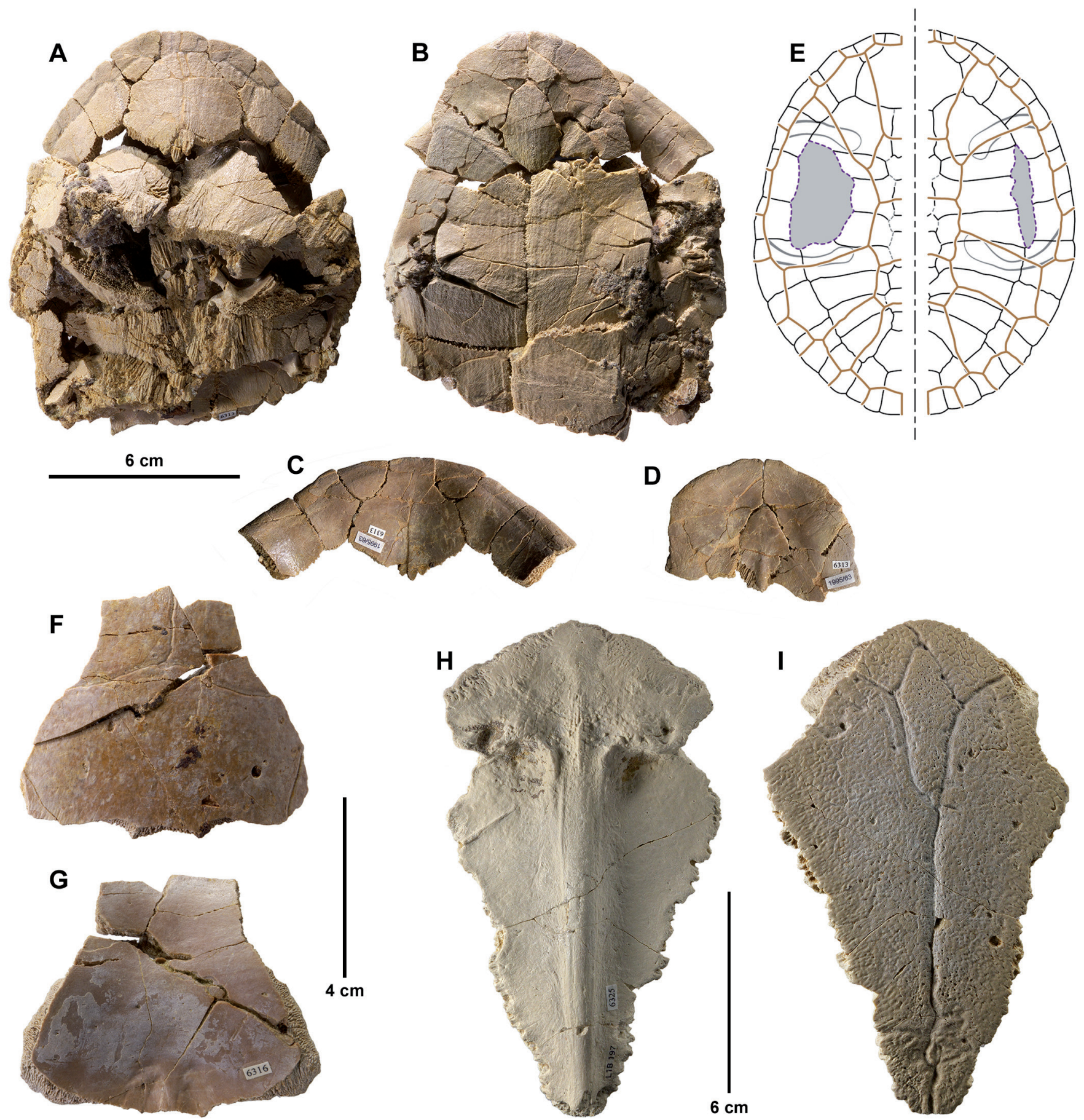

\section{H}
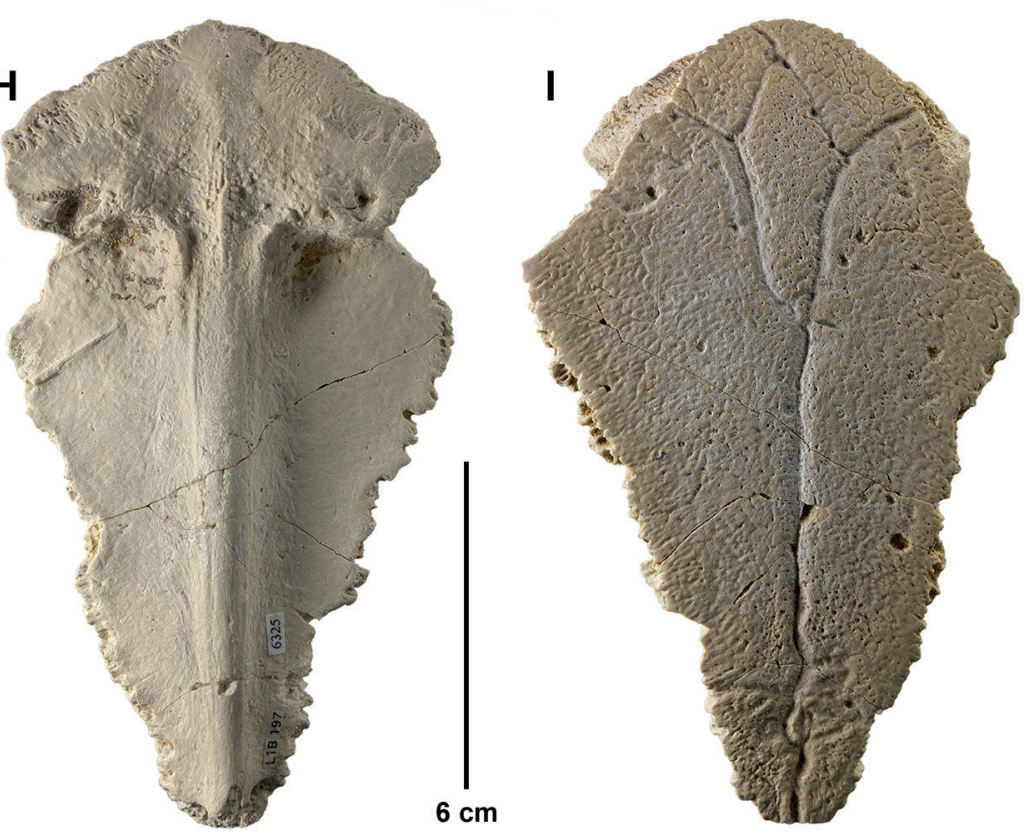

Fig. 5.- Turtle taxa defined in Laño. A-E, Dortoka vasconica Lapparent de Broin and Murelaga, 1996 (Dortokidae): A-B, MCNA 6313, holotypic partial shell in dorsal and ventral views; C, anterior part of the carapace (nuchal and first three pairs of peripherals) in ventral view; D, anterior plastral lobe (epiplastra and entoplastron) in dorsal view; E, reconstruction of the carapace showing the range of variability of this taxon, including that related to the size of the fontanelles (redrawn from Pérez-García et al., 2012a); F-G, Polysternon atlanticum Lapparent de Broin and Murelaga, 1996 (Bothremydidae): MCNA 6316, holotypic nuchal in dorsal and ventral views; H-I, Solemys vermiculata Lapparent de Broin and Murelaga, 1996 (Solemydidae): MCNA 6325, holotypic entoplastron in dorsal and ventral views.

(e.g., maxillae), mandibular remains and teeth from Laño, Buscalioni et al. (1997) erected Acynodon iberoccitanus and Musturzabalsuchus buffetauti (Fig. 6); these taxa were assigned to the Eusuchia as members of Alligatoroidea. In addition, Buscalioni et al. (1999) recognized two other taxa in Laño: an unnamed eusuchian, probably belonging to $\mathrm{Al}$ - lodaposuchus, and Ischyrochampsa-like taxon with uncertain affinities. Isolated postcranial elements of Laño were provisionally regarded as indeterminate. At least procoelous vertebrae belong to eusuchians.

Acynodon is a brevirostrine eusuchian of small size (about $1 \mathrm{~m}$ long). The genus is characterized by a wide, short and flat 
snout and heterodont dentition without caniniform teeth. The dentition comprises a gradation of spatulated anterior teeth to globular (tribodont) posterior ones (Buscalioni et al., 1999; Martin, 2007). The absence of caniniform teeth coupled with the presence of enlarged molariform teeth suggests that Acynodon probably fed on slowly moving hard-shelled preys (Delfino et al., 2008). The phylogenetic analyses placed Acynodon as a basal member of Globidonta within Alligatoroidea (Buscalioni et al., 1999, Martin, 2007, Delfino et al., 2008). The description of new complete skulls from France and Italy (Martin, 2007; Delfino et al., 2008) as Acynodon promoted the revision of the European material to verify its alligatoroidean origin by other authors since an alternative phylogenetic hypothesis putatively placed this peculiar eusuchian within Hylaeochampsidae (Brochu et al., 2012).

Musturzabalsuchus is larger in size than Acynodon. The rostrum of Musturzabalsuchus is unique in having a maxilla with a conspicuous curvilinear lateral contour and a mid-constriction (Buscalioni et al., 1997, 1999). M. buffetauti is considered to be a basal member of Alligatoroidea (Buscalioni et al., 1999; Narváez and Ortega, 2011). However, the status of this taxon remains uncertain and its relationships with other basal eusuchians from the Late Cretaceous of Europe, such as Allodaposuchus and Massaliasuchus, are an open question (Martin and Delfino, 2010).

The presence of a third eusuchian taxon in Laño distinct from Acynodon and Musturzabalsuchus is based on an isolated basicranial bone (Buscalioni et al., 1999). This material was referred to Allodaposuchus precedens in the revision made by Buscalioni et al. (2001). The genus Allodaposuchus is a major component of the Late Cretaceous crocodyliform faunas of Europe (Martin and Delfino, 2010), and it shows a wide spectrum of variation. Generally placed as the sister taxon of the Crocodylia crown group, it still needs a more comprehensive revision for a precise phylogenetic standing (Buscalioni et al., 2001, 2011; Pol et al., 2009; Martin, 2010; Puértolas et al., 2014).

Finally, isolated large teeth from Laño have been compared with those of Ischyrochampsa meridionalis (Buscalioni et al., 1999). This taxon was originally described as a member of Trematochampsidae (Vasse, 1995), a wastebasket taxon of ziphodont crocodyliforms. Ischyrochampsa has been regarded as a member of Neosuchia (Buscalioni et al., 2003), but its relationships remain currently unclear.

\subsection{Dinosaurs}

Laño has yielded numerous dinosaur remains. Titanosaurian sauropods are the best represented dinosaurs in number of specimens, followed by theropods (mostly teeth), ankylosaurs, and ornithopods. In number of species, theropods are the most diverse. At least ten distinct species have been identified in Laño; only the sauropod Lirainosaurus astibiae has been defined to date on the basis of the Laño material (Tables 1, 3).

\section{Theropods}

The Laño theropods have not yet been described in detail: the material consists of several vertebrae and limb bones, and more than a hundred isolated teeth. As far as known, Laño is the richest site in theropod teeth from the Late Cretaceous of Europe (see Ösi et al., 2010). Torices (2007) identified six different morphotypes, which could correspond to five species of small theropods and a sixth species of large size. All the small-sized theropod teeth (crown tooth height less than $17.5 \mathrm{~mm}$ ) correspond to coelurosaurians: Coelurosauria indet., cf. Richardoestesia sp., a tiny maniraptoran that may be a new taxon, and two dromaeosaurids: cf. Pyroraptor olympus (originally described in the Trets locality of Provence; see Allain and Taquet, 2000), and Dromaeosauridae indet. (Torices, 2007; Torices et al., in press). In addition, two tooth morphotypes of large size (crown height up to $62 \mathrm{~mm}$ ) could correspond to juvenile and adult individuals of the same taxon. These teeth are tentatively assigned to Theropoda indet. (Torices et al., in press). It has been discussed if these teeth could belong to neoceratosaurians but they lack ornamentation in the tooth enamel characteristic of this group and in the statistical analyses they showed stronger affinities to Tyrannosauridae. Due to these statistically uncertain affinities they are identified only as indeterminate theropods (Torices et al., in press). With regard to postcranial material, a pair of femora found at Laño has been compared to that of the abelisauroid Tarascosaurus from the Campanian of Provence (Le Loeuff and Buffetaut, 1991; Le Loeuff, 1992). Finally, an isolated tibiotarsus exhibits bird-like features and a partial sacrum first provisionally regarded as pterosaurian actually belongs to a large ground bird probably related to Gargantuavis (Buffetaut et al., 2006; and work currently in progress).

\section{Sauropods}

All the sauropod remains from Laño are referred to the titanosaur Lirainosaurus astibiae. This taxon was originally described on the basis of a skull fragment, isolated teeth, several vertebrae (e.g., holotypic anterior caudal vertebra; Fig. 7), appendicular bones and osteoderms (Sanz et al., 1999). New material, including basicranial, axial and appendicular elements, provides further information about the skeletal anatomy of Lirainosaurus (Díez Díaz et al., 2011, 2012, 2013a, 2013b, 2013c; Díez Díaz, 2013). Besides Laño, remains of Lirainosaurus have also described in other Iberian sites (Company et al., 2009; Ortega and Pérez-García, 2009; Díez Díaz, 2013). This taxon is diagnosed by autopomorphic features observed in the basicranium, vertebrae, and appendicular bones. More than a hundred teeth of Lirainosaurus have been collected in Laño; this sample is one of the largest known for titanosaurs. Tooth differences in size, morphology, ornamentation and microwear are regarded as ontogenetic changes; a switch in the diet and food processing between the juvenile and adult individuals has been hypothesized (Díez 

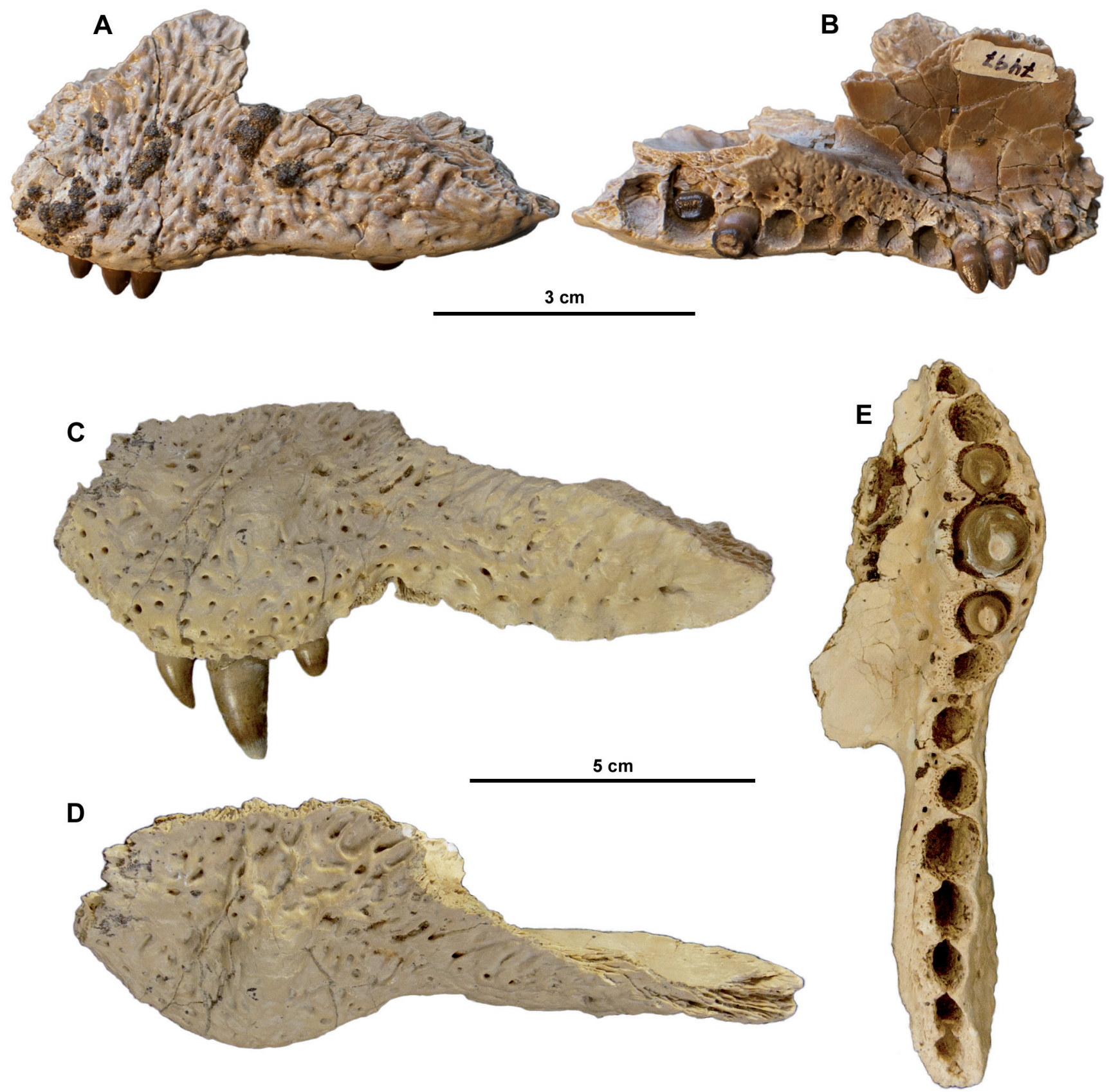

Fig. 6.- Eusuchian crocodylians defined in Laño: A-B, Acynodon iberoccitanus Buscalioni, Ortega and Vasse, 1997: MCNA 7497, holotypic left maxilla in dorsal and ventral views; C-E, Musturzabalsuchus buffetauti Buscalioni, Ortega and Vasse, 1997: MCNA 1881, holotypic left maxilla in lateral, dorsal and ventral views.

Díaz et al., 2012). Lirainosaurus was a small and slender titanosaur (estimated body size up to $6 \mathrm{~m}$ and 2 to 4 tn of body mass for the largest individuals; Díez Díaz, 2013; Díez Díaz et al., 2013b). It is considered to be a derived lithostrotian member of Saltasauridae. L. astibiae is the only titanosaurian species erected to date from the Late Cretaceous sites of the Iberian Peninsula.

\section{Ankylosaurs}

Armoured dinosaurs are represented in Laño by a partial skeleton (synsacrum, pelvis and hindlimb bones) and scat- tered elements, including maxilla and lower jaw remains, isolated teeth, vertebrae and ribs, limb bones, and osteoderms (Pereda Suberbiola, 1993a, 1999). These remains have been assigned to the ankylosaur Struthiosaurus on the basis of features observed in the lower jaw, synsacrum, pelvis, and dermal armour (Pereda Suberbiola et al., 1995; Garcia and Pereda Suberbiola, 2003). Due to minor differences relative to known species of Struthiosaurus from the Campanian-Maastrichtian of Europe, the Laño material is tentatively referred to as Struthiosaurus sp. Struthiosaurus was a dwarf ankylosaur, with adults having a body length less than $3 \mathrm{~m}$ (Pereda Suberbiola and Galton, 2009). This dinosaur is a member of 

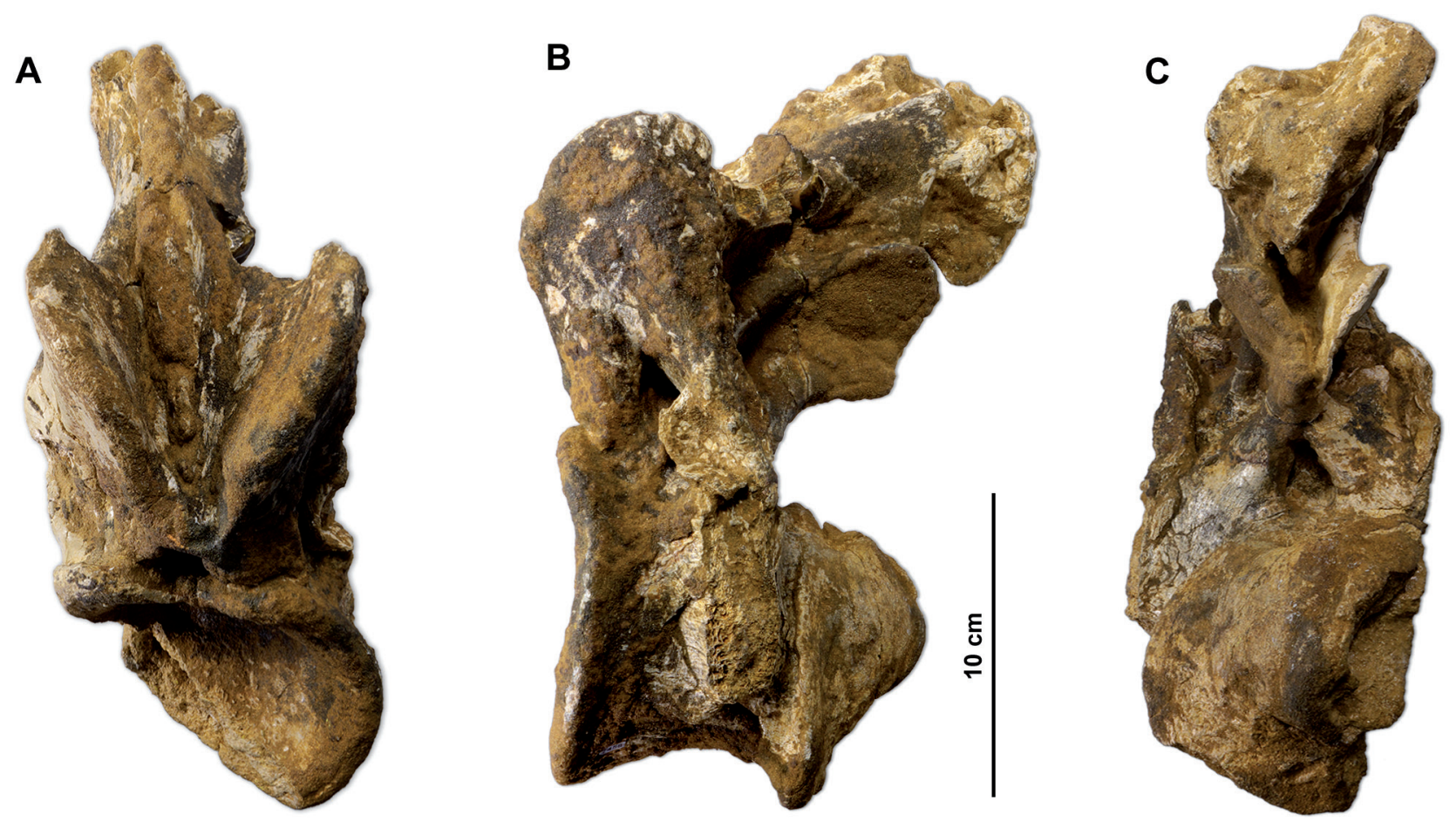

Fig. 7.- Sauropod dinosaur defined in Laño: A-C, Lirainosaurus astibiae Sanz et al., 1999: holotype MCNA 7458, anteriormost caudal vertebra in anterior, left lateral and posterior views.

Nodosauridae (Pereda Suberbiola, 1993b; Thompson et al., 2012), the only known clade of ankylosaurs from the latest Cretaceous of Europe.

\section{Ornithopods}

Ornithopod remains are scarce at Laño, but at least two taxa are represented. Isolated teeth, vertebrae and limb bones (humerus, femora) have been referred to the basal iguanodontian Rhabdodontidae Rhabdodon sp. (Pereda Suberbiola and Sanz, 1999). Rhabdodontids are a group of basal ornithopods endemic to Europe (Weishampel et al., 2003; Ösi et al., 2012). In addition, Laño has yielded a single tooth belonging to an indeterminate hadrosauroid (Pereda Suberbiola et al., 2003). Consequently, this latter finding testifies of the co-existence of rhabdodontids and hadrosauroids in the latest Cretaceous of the Iberian Peninsula. Based on an incomplete ilium, the presence of a third ornithopod taxon in Laño is worthy of consideration (this material remains currently undescribed).

\subsection{Pterosaurs}

Laño is one of the most productive pterosaur sites from the Late Cretaceous in Europe. Pterosaur remains consist of an edentulous jaw fragment, elements of the vertebral column (cervical vertebrae, notarium), and limb bones (wing bones, femora) belonging to several individuals (Astibia et al., 1990; Buffetaut, 1999). Some of these bones have not yet been described in detail. Metacarpal (length $346 \mathrm{~mm}$ ) and several phalanges of the fourth finger suggest a minimum wingspan of 3 to $3.5 \mathrm{~m}$, which means they were large but not gigantic pterosaurs. The material obtained was referred to an indeterminate azhdarchid (Astibia et al., 1990), and later regarded as cf. Azhdarcho sp. because of close resemblances with Azhdarcho lancicollis from the Turonian of Uzbekistan in Central Asia, mainly on the basis of jaw morphology and general size (Buffetaut, 1999). Azhdarchid remains are relatively common in the latest Cretaceous continental sites of Europe (Company et al., 1999; Barrett et al., 2008; Buffetaut, 2008; Averianov, 2014) and new taxa have recently been described (Ösi et al., 2005; Vremir et al., 2013 and references). Pending a full description of this material, the Laño pterosaur is provisionally referred to Azhdarchidae indet.

\subsection{Mammals}

The mammal assemblage of Laño is the richest known in the latest Cretaceous of southern Europe. It consists of 20 isolated teeth, i.e. molars, premolars, including deciduous teeth, and an incisor (Gheerbrant and Astibia, 1994, 1999, 2012). The faunule is composed exclusively of therian forms, and more specifically of zhelestid eutherians. Zhelestids are dentally ungulate-like mammals, but were recently excluded from Placentalia (Wible et al., 2009) and are instead considered as herbivorous stem eutherians of Cretaceous Asian origin (Gheerbrant and Astibia, 1999; Archibald and Averianov, 2012).

The zhelestids from Laño and other European sites are included in the subfamily Lainodontinae Gheerbrant and 
Astibia, 2012, which documents a modest mammal radiation of five or six species restricted to Europe. Three different species of the lainodontine genus Lainodon have been documented in Laño (Fig. 8): L. orueetxebarriai (Gheerbrant and Astibia, 1994, 1999), L. ragei and a still unnamed species (Gheerbrant and Astibia, 2012). The zhelestid mammals are characterized by a crushing-grinding dietary adaptation related to an early herbivorous trend among eutherians. The Lainodontinae (Zhelestidae) is the most diverse and dominant taxon in the Late Cretaceous mammalian faunas of Western Europe, by contrast to Central European sites that include only kogaionid multituberculates (Kielan-Jaworowska et al., 2004; Gheerbrant and Astibia, 2012). The Zhelestidae family has been treated as paraphyletic, but recent phylogenetic work supports its monophyly (Archibald and Averianov, 2012).

\section{The vertebrate fossil assemblage from the shallow marine beds of Albaina}

A rich vertebrate assemblage has also been recovered from some calcarenites, and in less quantity from interbedded friable sandstones, which form the uppermost beds of the depositional cycle DC-13. This shallow marine assemblage has yielded at least thirty seven species including sharks and rays, pycnodontiforms, teleosteans, mosasaurids, and plesiosaurs (Table 3). Most of the material consists of isolated teeth but other skeletal remains occur as indicated below. In addition, new vertebrate fossils collected in the Albaina beds consist of partial turtle plates and a fragmentary dinosaur femur (Pereda Suberbiola et al., in press).

\subsection{Selachians}

Cartilaginous fishes are represented by isolated teeth, indeterminate selachian dermal denticles, thorns and tail spines. The association recovered from the Albaina site, which was studied by Cappetta and Corral (1999), is particularly rich in shark and ray teeth and has yielded so far 15 genera, including two new genera, and 19 species of selachians, four of which are new rhinobatoid ray species (Fig. 9; see also Table 3).

Shark taxa consists of lamniforms (the anacoracids Squalicorax pristodontus and S. kaupi; the otodontid Cretolamna appendiculata, the serratolamnid Serratolamna serrata; the odontaspidids Carcharias heathi, Carcharias aff. gracilis and Odontaspis bronni), orectolobiforms (the ginglymostomatids Plitacoscyllium lehneri and the hemyscyllid Chiloscyllium
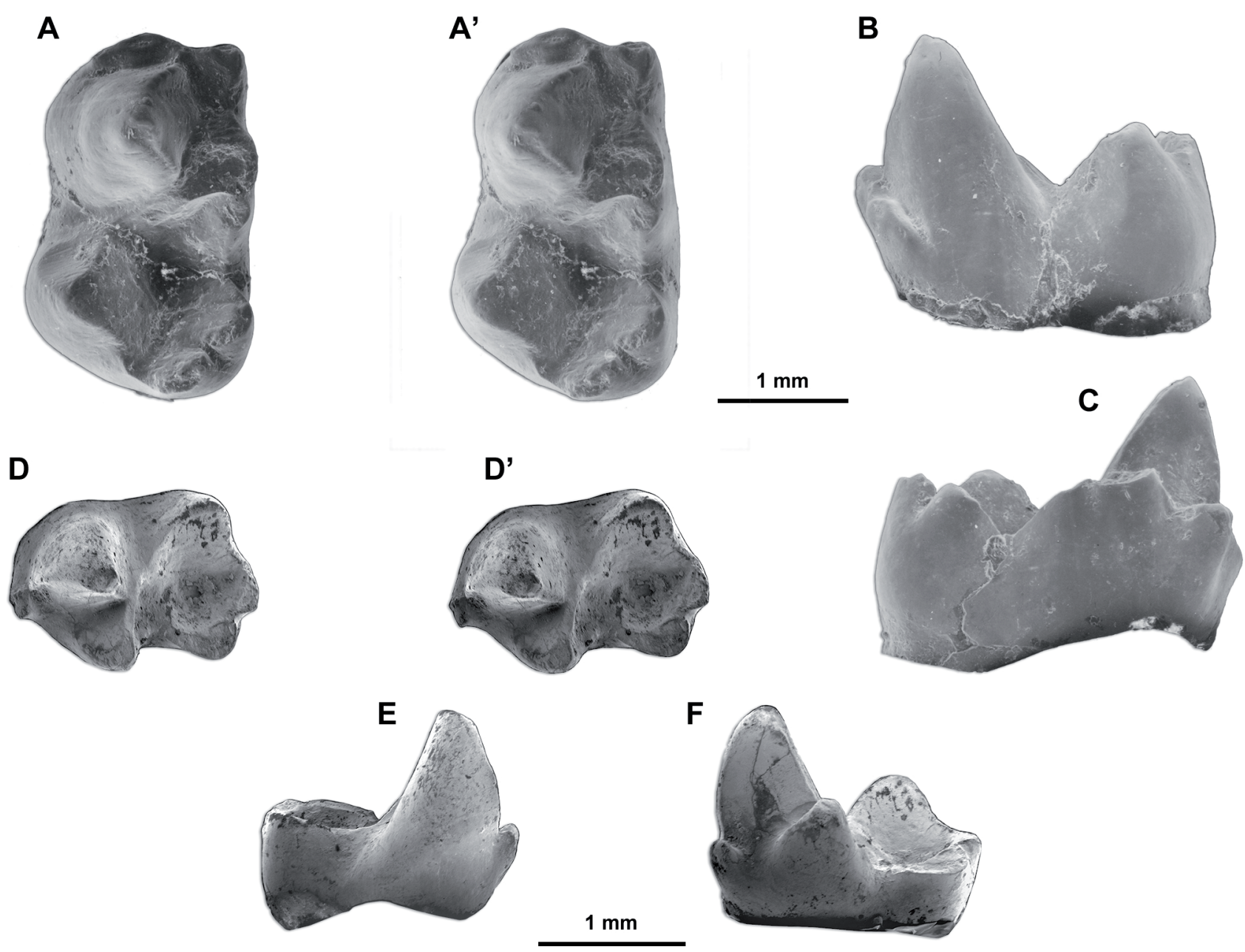

F

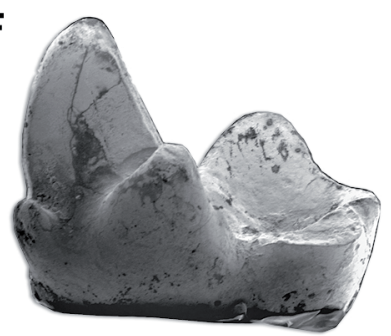

Fig. 8.- Eutherian mammals defined in Laño: A-C, Lainodon orueetxebarriai Gheerbrant and Astibia, 1994: holotype MCNA L1A T4, left M/1 in occlusal, labial and lingual views; and D-F, Lainodon ragei Gheerbrant and Astibia, 2012: holotype MCNA L1AT 15, right dP/5 in occlusal, labial and lingual views. 
Table 3. Updated list of vertebrates from the shallow marine beds of Albaina (Late Maastrichtian).

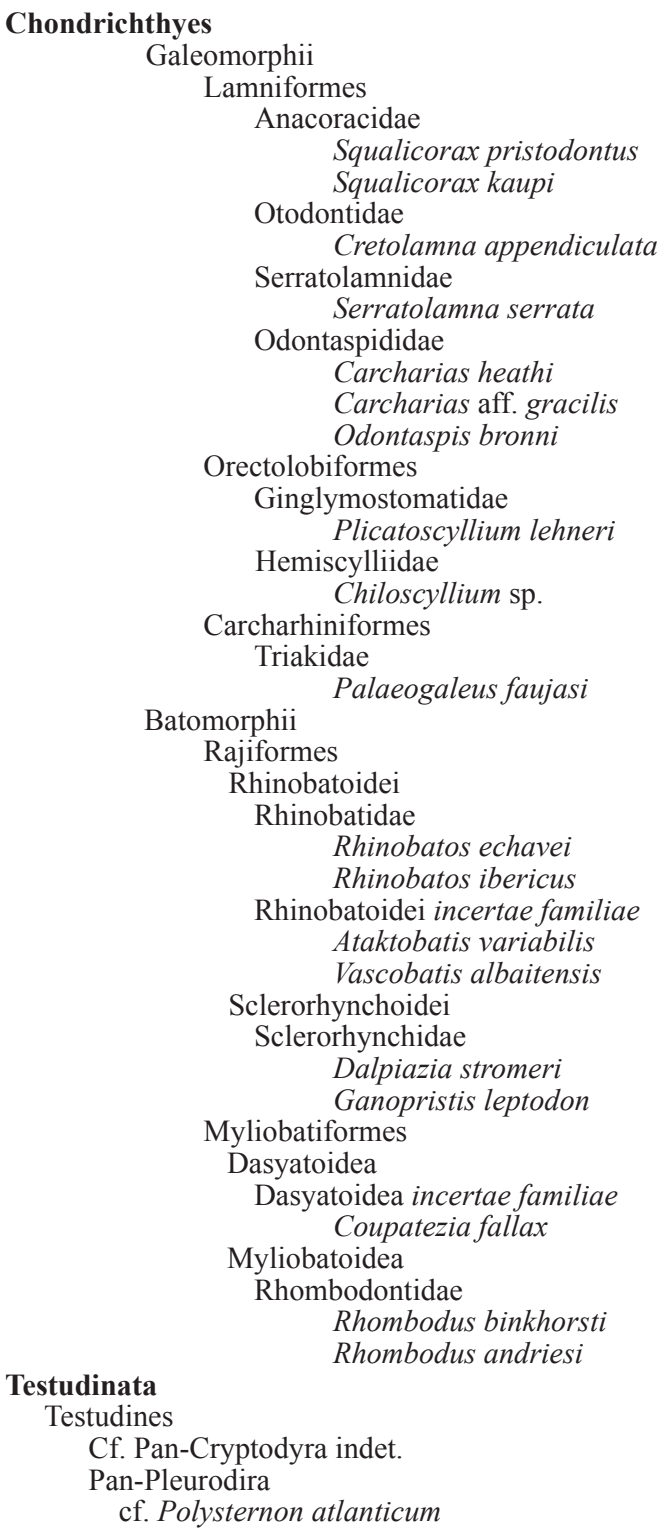

sp.), and carcharhiniforms (the triakid Palaeogaleus faujasi). Rays include rajiforms (the rhinobatids Rhinobatos echavei and R. ibericus and the rhinobatoids incertae familiae Ataktobatis variabilis and Vascobatis albaitensis, all of them first defined in Albaina; the sclerorhynchids Dalpiazia stromeri and Ganopristis leptodon) and myliobatiforms species (the dasyatoid Coupatezia fallax, the rhombodontids Rhombodus andriesi and R. binkhorsti) (Cappetta and Corral, 1999; see Table 2 for the faunal list found in the locality).

Cappetta and Corral (1999) described the occurrence of Plicatoscyllium minutum (Forir, 1887) in Albaina. However, a closer study of the original material of Plicatoscyllium lehneri (Leriche, 1938) allowed to confirm it as a valid species, not a senior synonym of the former, and therefore the assignment of the Ginglymostomatidae teeth found in Albaina to Plicatoscyllium lehneri.

The selachian association of Albaina indicates a Maastrichtian age, and more precisely a Late -but not latest- Maastrich-

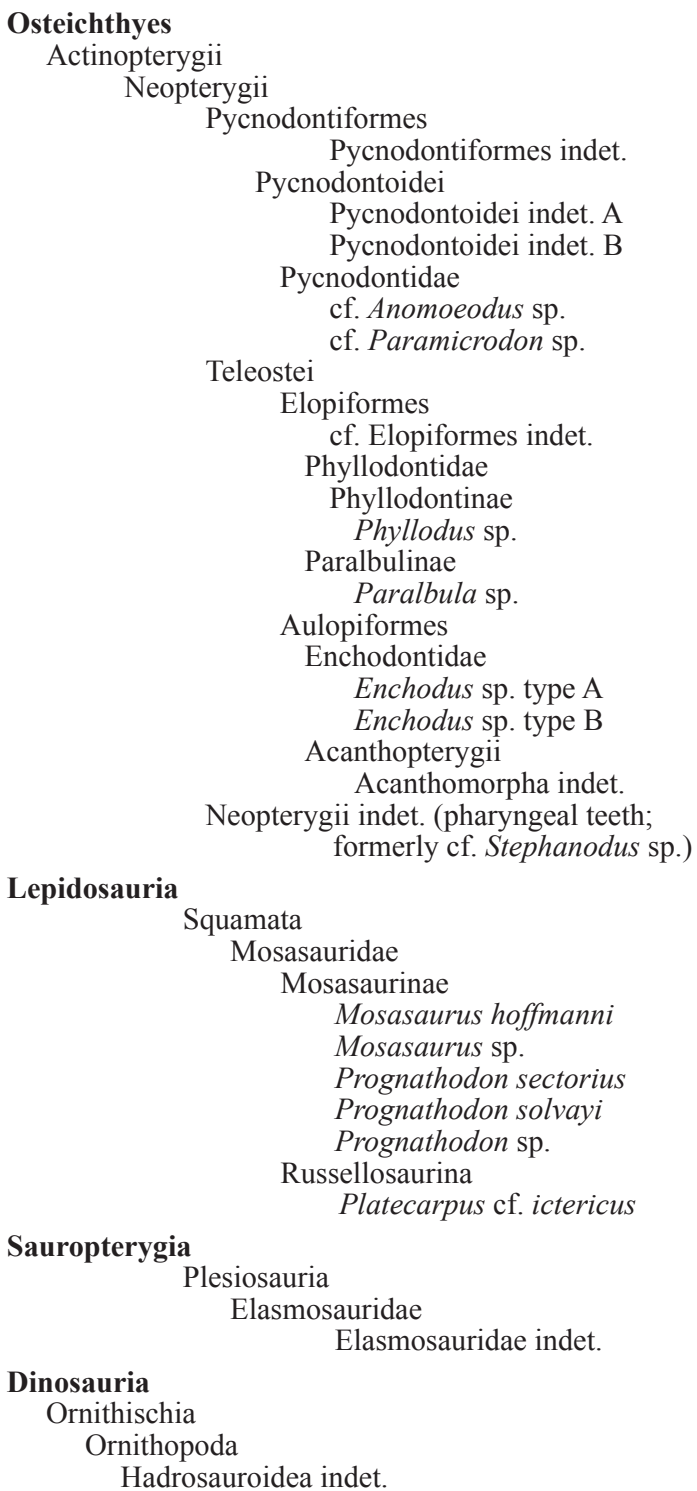

tian age according to the presence of Rhombodus andriesi and Odontaspis bronni species. In sum, the Albaina site is the most productive Late Cretaceous locality of fossil selachian remains in the Iberian Peninsula and among the most diverse Late Cretaceous sites of southwestern Europe.

\subsection{Actinopterygians}

The Albaina beds have yielded a relatively diverse actinopterygian ichthyofauna (Poyato-Ariza et al., 1999). Most of the remains consist of isolated teeth and tooth plates, although a few vertebral centra and fragments of fin spines are also known. The total number of specimens is about 800 .

Poyato-Ariza et al. (1999) provided a conservative approach to the identification of the Albaina actinopterygian remains based on morphotypes rather than strict taxonomical identification. Twelve tooth morphotypes were distinguished, which may correspond to a maximum diversity of 12 taxa, 

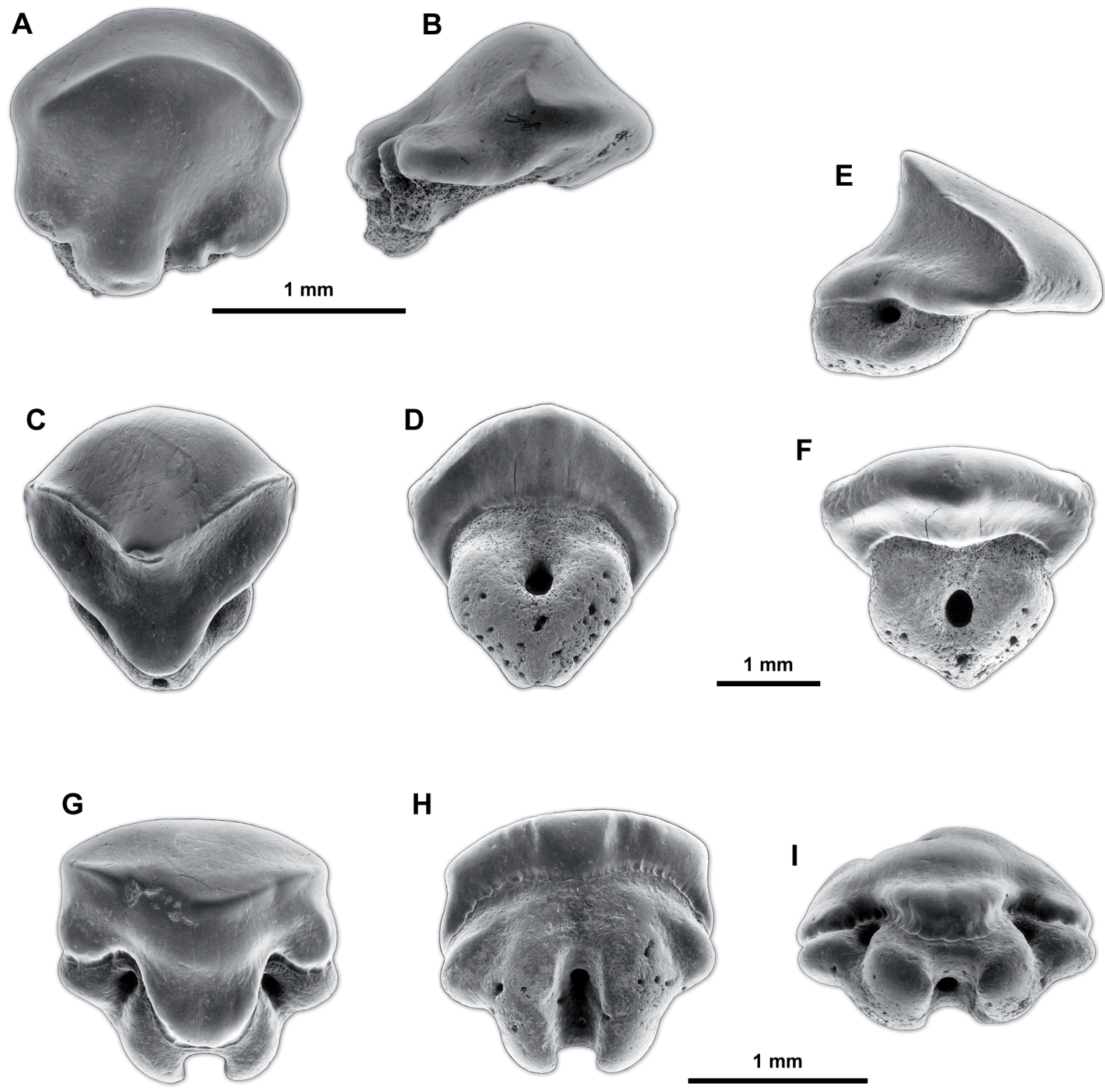

H

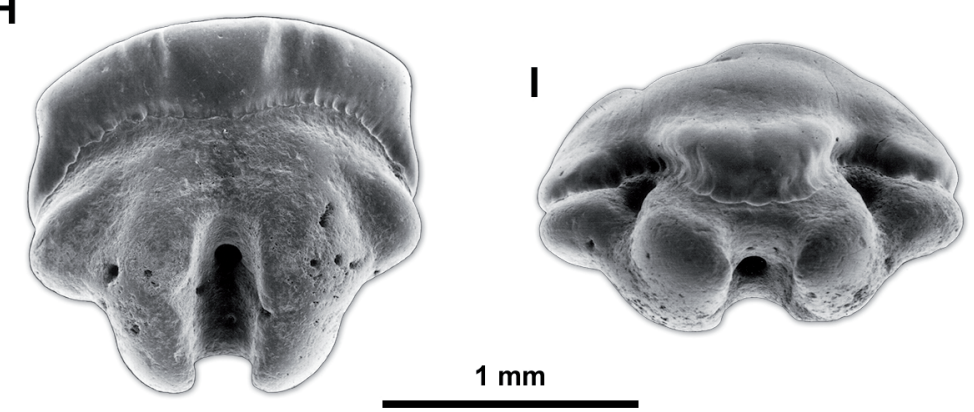

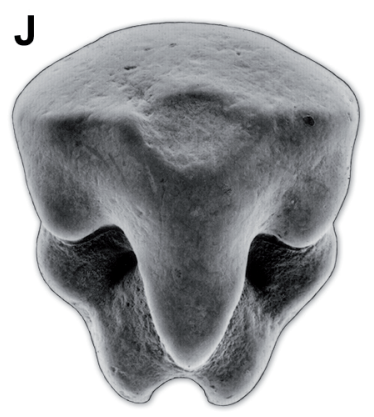
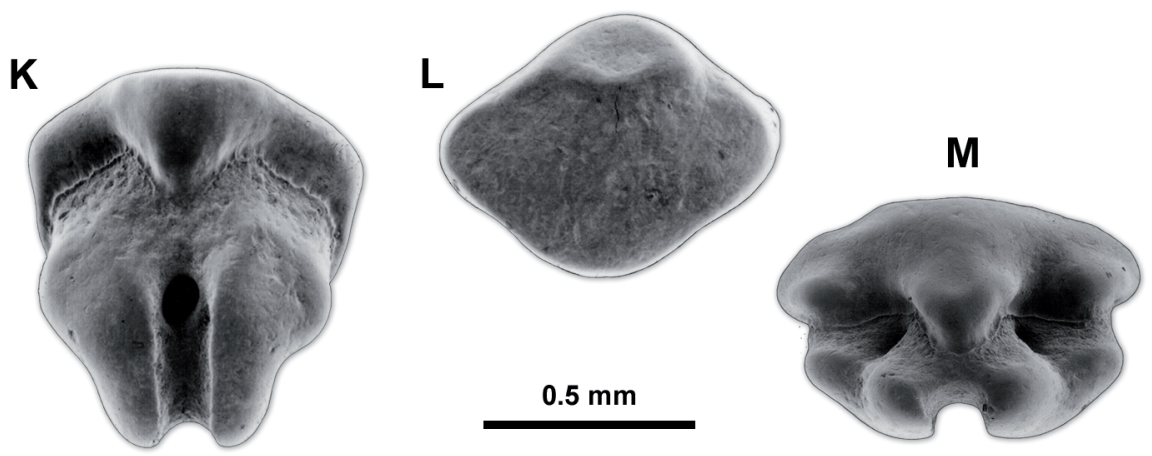

Fig. 9.- Rhinobatoid rays defined in Albaina: A-B, Ataktobatis variabilis Cappetta and Corral, 1999: holotype MCNA 8267, lateral tooth in occlusal and profile views; C-F, Vascobatis albaitensis Cappetta and Corral, 1999: holotype MCNA 8281, anterolateral tooth in occlusal, basal and oblique basal views; G-I, Rhinobatos echavei Cappetta and Corral, 1999: holotype MCNA 8272, lateral tooth in occlusal, basal, labial and lingual views; J-M, Rhinobatus ibericus Cappetta and Corral, 1999: holotype MCNA 8279, anterolateral tooth in occlusal, basal and lingual views. Photographs from Cappetta and Corral (1999). 
including pycnodontiforms and teleosteans. Five morphotypes may correspond to pycnodonts: Pycnodontiformes indet. (pharyngeal teeth), Pycnodontoidei indet. A (flattened, ellipsoidal-like tooth), Pycnodontoidei indet. B (incisiform teeth), cf. Anomoeodus sp. (flattened, comma-shaped tooth), and cf. Paramicrodon sp. (vomerian tooth plate). Because of the heterodonty in pycnodonts, two or more of these morphotypes may coexist in the same taxon. The teleostean tooth morphotypes of Albaina may correspond to: cf. Elopiformes indet. (vertebral centra); the phyllodontids Phyllodus sp. (parasphenoid tooth plate and isolated teeth) and Paralbula sp. (basibranchial tooth plate and isolated teeth); the aulopiform Enchodus sp. (two morphotypes of caniniform teeth, which may or may not correspond to different species); and Acanthomorpha indet. (basal fragments of fin spines). The pharyngeal teeth tentatively previously assessed to cf. Stephanodus sp. fit into the morphologic variability of the pharyngeal teeth of pycnodonts and other groups (e.g., Thies, 1989; Poyato-Ariza and Wenz, 2002, 2005), so they probably do not represent a distinct taxon and are better considered Neopterygii indet. The most abundant taxon is by far Paralbula sp. (about $70 \%$ of the actinopterygian teeth), followed by $E n$ chodus spp. (20\%).

The actinopterygian association of Albaina is similar to that found in the nearby site of Quintanilla la Ojada (Burgos province) (Berreteaga et al., 2011), probably due to taphonomic processes that selectively destroyed less durable remains. As in other Iberian coeval localities, the associations of Albaina and Quintanilla la Ojada show a mixture of some teleosteans plus diversified relict, non-teleostean forms (such as pycnodontiforms). This is a nice example of the replacement process that would turn the actinopterygian composition of aquatic ecosystems during the Late Cretaceous in this part of the world into the modern, teleostean-dominated ichthyofaunas (Poyato-Ariza et al., 1999; Berreteaga et al., 2011; PoyatoAriza and Martín-Abad, 2013).

\subsection{Mosasaurids}

Mosasaurid material from Albaina consists primarily of a collection of isolated teeth and vertebrae. At least five distinct taxa have been recognized on the basis of tooth features: Mosasaurus hoffmanni, Mosasaurus sp., Prognathodon sectorius, Prognathodon solvayi, Prognathodon sp., and Platecarpus cf. ictericus (Bardet et al., 1997, 1999, 2013). As in other latest Cretaceous mosasaurid associations, Mosasaurinae taxa are dominant relative to Russellosaurina ones. Albaina has yielded the most diverse mosasaurid assemblage found to date in the Iberian Peninsula (Bardet et al., 2008, 2013).

\subsection{Plesiosaurs}

Plesiosaurs are represented by a single elasmosaurid tooth (Bardet et al., 1999). This is the only record of Elasmosauri- dae in the Late Cretaceous of the Iberian Peninsula (Bardet et al., 2008), and one of the scarce mentions of this clade in the Maastrichtian of Europe (Vincent et al., 2011).

\subsection{Turtles}

The material consists of two partial turtle plates, one of them belonging to a member of Bothremydidae (Pleurodira) and the other to an indeterminate taxon, probably corresponding to a Pan-Cryptodira (Pereda-Suberbiola et al., in press).

\subsection{Dinosaurs}

The first dinosaur fossil found in the sublittoral beds of Albaina is a fragmentary ornithopod femur, which can be interpreted as the result of the passive transport of a floating carcasse from the mainland. It is one of the few hadrosauroid remains from the Late Maastrichtian of Europe found in marine environments, and the first one described from sublittoral deposits in the Iberian Peninsula (Pereda-Suberbiola et $a l$. in press).

\section{Significance of the vertebrate associations from the Laño quarry.}

The Laño quarry is one of the most noteworthy Late Cretaceous vertebrate localities of Europe, taking into account both fossil richness and taxonomic diversity. Considering the terrestrial and freshwater vertebrates, at least 37 species are known in the Late Campanian to Early Maastrichtian beds, making it the most diverse association hitherto known for this age in Europe (Astibia et al., 1990, 1999b). Of the nearly 40 tetrapod families (or higher-level taxa) recorded in the Santonian-Maastrichtian of Europe (Pereda Suberbiola, 2009), at least 23 are known in Laño. Laño enlarges our knowledge of the latest Cretaceous faunas: it includes one of the oldest records of both Salamandridae and Palaeobatrachidae lissamphibians in the world (Duffaud and Rage, 1999), and one of the oldest records of amphisbaenians or anguids in Europe (Rage, 1999). The squamate association is one of the richest and most diverse known from the Cretaceous of Europe (Rage, 1999, 2013; LaDuke et al., 2010). Besides, the Laño fluvial beds have yielded fossil remains leading to the erection of a number of reptilian taxa that are widely represented in the latest Cretaceous localities of Europe, such as the turtles Solemys and Dortoka (Lapparent de Broin and Murelaga, 1999; Pérez-García et al., 2012a) and the crocodilians Acynodon and Musturzabalsuchus (Buscalioni et al., 1999; Martin and Delfino, 2010). With regard to the dinosaurs, the non-avian theropod association of Laño is the most diversified of the Campanian-Maastrichtian of Europe (Torices et al., in press); and the sauropod Lirainosaurus is currently the best known titanosaur of Europe (Díez Díaz et al., 2011, 2012, 2013a, 2103b; Díez Díaz, 2013). Finally, the mammalian faunule of Laño is one of the richest hitherto discovered in Europe and 
provides data on the evolution of early eutherians (Gheerbrant and Astibia, 2012).

The vertebrate fossil association of Laño is considered to be a typical continental faunal assemblage from the Late Campanian-Early Maastrichtian of the Ibero-Armorican Domain (SW Europe). Other relevant sites of the same age are: Chera in Valencia (Company et al., 1999) and Lo Hueco in Cuenca (Ortega et al., 2008, 2015), in the Iberian Peninsula; Bellevue in Campagne-sur-Aude (Aude), Cruzy (Hérault), La Boucharde in Trets, Velaux-Bastide Neuve (both in Bouchesdu-Rhône), and Fox-Amphoux (Var), in Languedoc and Provence (Le Loeuff, 1992; Garcia et al., 2000, 2010; Laurent et al., 2001; Allain and Pereda Suberbiola, 2003; Buffetaut, 2005). These vertebrate fossil assemblages are mainly dominated by titanosaurian sauropods, rhabdodontid ornithopods, nodosaurid ankylosaurs and dromaeosaurid theropods among dinosaurs, alligatoroid crocodyliforms, bothremydid and solemydid turtles, and zhelestid mammals. Other common components of the faunas are lepisosteid actinopterygians, the dortokid turtle Dortoka, the basal eusuchian Allodaposuchus and closely related forms, abelisauroid theropods and azhdarchid pterosaurs. A number of taxa that have been recorded in other Ibero-Armorican sites are apparently absent in Laño, i.e., sparid fishes, batrachosauroid urodeles, sebecosuchian-like crocodilians, and enantiornithine birds (see Le Loeuff, 1991; Buffetaut et al., 1997; Pereda Suberbiola, 2009; Csiki et al., 2015).

The continental vertebrate faunas from the CampanianMaastrichtian of southwestern Europe show biogeographical affinities with those of the Laurasian landmasses, either from Palaeolaurasia (sensu Russell, 1993, i.e., Central Asia with North America and probably Europe), Euramerica, Asia or endemic to Europe, but also contain Gondwanan elements (Astibia et al., 1990; Le Loeuff, 1991; Rage, 2002; Pereda Suberbiola, 2009). The picture that emerges is that of continental faunas that evolved isolated in the European archipelago as a result of vicariance during the Late Cretaceous. The isolation from other landmasses may have facilitated the survival of relict (vicariant) taxa in Europe until Campanian-Maastrichtian times. Moreover, dispersal events between Asia (and, tentatively, between North America) and Europe have been documented during the Late Cretaceous (see Pereda Suberbiola, 2009; Weishampel et al., 2010; Prieto-Márquez et al., 2013; Csiki et al., 2015 and references therein). The faunal exchanges that are hypothesized to occur between the Gondwanan landmasses and Europe during the Late Cretaceous are still matters of debate (Gheerbrant and Rage, 2006).

With regard to the marine vertebrate association of Albaina, which is composed of selachians, actinopterygians, mosasaurids, and plesiosaurs, as noted earlier, at least 37 species are recorded from these Late Maastrichtian shallow sublittoral beds. As a result, this is the most diverse assemblage of marine vertebrates found so far in the latest Cretaceous of the Ibero-Armorican Realm (southern Europe). The selachian as- sociation of Albaina is original in showing a mixture of both southern Tethyan (Moroccan phosphatic basins) and northern European boreal (Belgian and German basins) species, but also containing some particular taxa, i.e. rhinobatoids (Cappetta and Corral, 1999; Corral, in prep.). The mosasaurid assemblage of Albaina is typical of the Northern Tethys margin palaeoprovince located around palaeolatitudes $30^{\circ}-40^{\circ} \mathrm{N}$ (Bardet, 2012). Recently, dinosaur and turtle remains have also been found in the Late Maastrichtian sublittoral beds of Albaina (Pereda-Suberbiola et al., in press). Turtle fossils belong to a member of Pleurodira (Bothremydidae) and probably to an indeterminate Pan-Cryptodira. The occurrence of dinosaurs in this shallow marine environment can be interpreted as the result of a passive transport from the mainland.

\section{Acknowledgments}

We would like to thank all of the people involved in the excavation and study of the fossil vertebrates from the Laño quarry, especially Mr. Juan Echave (ECHASA) and Mr. Jesús Alonso (Museo de Ciencias Naturales de Álava/Arabako Natur Zientzien Museoa, Vitoria-Gasteiz). We are grateful to the referees Drs. Attila Ösi (Budapest) and David B. Weishampel (Baltimore) for their constructive comments on the manuscript. Field research in the Laño quarry has been supported by financial aids of the Ministerio de Economía y Competitividad (MINECO projects CGL2010-18851/BTE and CGL2013-47521-P), Ministerio de Ciencia e Innovación (CGL2007-64061/BTE), Ministerio de Ciencia y Tecnología (CGL2004-02338/BTE, BTE2001-0185-C02-01, BOS20001369), Ministerio de Educación y Ciencia (Acción Integrada hispano-francesa 201-B), Diputación Foral de Álava/Arabako Foru Aldundia (93/23, 95/A23), Gobierno Vasco/Eusko Jaurlaritza (IT834-13, IT-320-10, IT-361-07, GV121.310-4/87), Universidad del País Vasco/Euskal Herriko Unibertsitatea (9/ UPV00121.310-15303/2003), Centre National de la Recherche Scientifique (CNRS, France), Institut National des Sciences de l'Univers (INSU), The Dinosaur Society (research grant 1997) and the National Geographic Research (grant \#6597-99). This work is part of a palaeontological collaboration (Convenio específico de colaboración) between the Universidad del País Vasco/EHU, the Centre National de la Recherche Scientifique (CNRS, France) and the Muséum National d'Histoire Naturelle (MNHN, Paris). Contribution ISEM n 2015-049.

\section{References}

Allain, R., Pereda Suberbiola, X. (2003): Dinosaurs of France. Comptes Rendus Palevol 2, 27-44. doi: 10.1016/S1631-0683(03)00002-2.

Allain, R., Taquet, P. (2000): A new genus of Dromaeosauridae (Dinosauria, Theropoda) from the Upper Cretaceous of France. Journal of Vertebrate Paleontology 20, 404-407. doi: 10.1671/0272-4634(2000)020[0404:ANGODD]2.0.

Anquetin, J. (2012): Reassessment of the phylogenetic interrelationships of basal turtles (Testudinata). Journal of Systematic Palaeontology 10, 3-45. doi: 10.1080/14772019.2011.558928. 
Apesteguía, S. (2012): The youngest European sphenodontian? A possible Late Campanian eilenodontine from the Baske Country. Abstracts $10^{\text {th }}$ Annual Meeting of the European Association of Vertebrate Palaeontologists, Teruel. Fundamental 20, 11-14.

Archibald, J.D., Averianov, A. (2012): Phylogenetic analysis, taxonomic revision, and dental ontogeny of the Cretaceous Zhelestidae (Mammalia: Eutheria). Zoological Journal of the Linnean Society 164, 361-426. doi: 10.1111/j.1096-3642.2011.00771.x

Astibia, H., García Garmilla, F., Orue-Etxebarria, X., Rodríguez Lázaro, J. (1986): Quelonios y arcosaurios en el Cretácico superior del País Vasco: Nota preliminar. Kobie (Serie Ciencias Naturales) 15, 195 198.

Astibia, H., García-Garmilla, F., Orue-Etxebarria, X., Rodriguez-Lazaro, J., Buscalioni, A.D., Sanz, J.L., Jimenez-Fuentes, E. (1987): The Cretaceous-Tertiary Boundary in a sector of the South Limb of the Miranda-Treviño Synclinal: the first appearance of Chelonia and Archosauria in the Basque Country. Cretaceous Research 8, 15-27. doi: 10.1016/0195-6671(87)90009-7.

Astibia, H., Buffetaut, E., Buscalioni, A.D., Cappetta, H., Corral, C., Estes, R., Garcia-Garmilla, F., Jaeger, J.J., Jimenez-Fuentes, E., Le Loeuff, J., Mazin, J.M., Orue-Etxebarria, X., Pereda-Suberbiola, J., Powell, J.E., Rage, J.C., Rodriguez-Lazaro, J., Sanz, J.L., Tong, H. (1990): The fossil vertebrates from Laño (Basque Country, Spain); new evidence of the composition and affinities of the Late Cretaceous continental faunas of Europe. Terra Nova 2, 460-466. doi: 10.1111/ j.1365-3121.1990.tb00103.x.

Astibia H., Corral J.C., Murelaga X., Orue-Etxebarria, X., Pereda-Suberbiola, X. (1999a): Introduction. Laño discovery: Palaeontological and Geocultural setting. Estudios del Museo de Ciencias Naturales de Álava 14 (Número especial 1), 7-12.

Astibia H., Corral J.C., Murelaga X., Orue-Etxebarria, X., Pereda-Suberbiola, X., coords. (1999b): Geology and palaeontology of the Upper Cretaceous vertebrate-bearing beds of the Laño quarry (Basque-Cantabrian Region, Iberian Peninsula). Estudios del Museo de Ciencias Naturales de Álava 14 (Número especial 1), 1-380.

Astibia, H., Murelaga, X., Pereda Suberbiola, X., Elorza J.J., GómezAlday, J.J. (1999c): Taphonomy and palaeoecology of the Upper Cretaceous continental vertebrate-bearing beds of the Laño quarry (Iberian Peninsula). Estudios del Museo de Ciencias Naturales de Álava 14 (Número especial 1), 43-104.

Augé, M.L. (2012): Amphisbaenians from the European Eocene: a biogeographical review. Palaeobiodiversity and Palaeoenvironments 92, 425-443. doi: 10.1007/s12549-012-0104-6.

Averianov, A. (2014): Review of taxonomy, geographic distribution, and paleoenvironments of Azhdarchidae (Pterosauria). Zookeys 432, 1-107. doi: 10.3897/zookeys.432.7913.

Baceta, J.I. (1996): El Maastrichtiense superior, Paleoceno e Ilerdiense inferior de la Region Vasco-Cantábrica: secuencias deposicionales, facies y evolución paleogeográfica. Unpublished Doctoral Thesis, Universidad del País Vasco/Euskal Herriko Unibertsitatea (UPV/ EHU), Leioa, 372 p.

Baceta, J.I., Pujalte, V., Orue-Etxebarria, X. (1999): The vertebrate fossil sites of the Laño quarry (Basque Cantabrian Region): stratigraphical and paleogeographical context. Estudios del Museo de Ciencias Naturales de Álava 14 (Número especial 1), 13-28.

Bardet, N. (2012): Maastrichtian marine reptiles of the Mediterranean Tethys: a palaeobiogeographical review. Bulletin de la Société Géologique de France 183, 573-596. doi: 10.2113/gssgfbull.183.6.573.

Bardet, N., Corral, J.C., Pereda Suberbiola, X. (1997): Les mosasaures (Squamata) du Crétacé supérieur du Bassin basco-cantabrique. Geobios 20, 19-26. doi: 10.1016/S0016-6995(97)80005-8.

Bardet, N., Corral, J.C., Pereda Suberbiola, X. (1999): Marine reptiles from the uppermost Cretaceous of the Laño quarry (Iberian Peninsu- 1a). Estudios del Museo de Ciencias Naturales de Álava 14 (Número especial 1), 373-380.

Bardet, N., Pereda Suberbiola, X., Ruiz-Omeñaca, J.I. (2008): Mesozoic marine reptiles from the Iberian Peninsula. Geo-Temas 10, 1245 1248 .

Bardet, N., Martin, G., Corral, J.C., Pereda Suberbiola, X., Astibia, H. (2013): New mosasaurid remains (Reptilia: Squamata) from the Maastrichtian of Albaina (Laño quarry, Condado de Treviño). Spanish Journal of Palaeontology 28, 69-78.

Barrett, P.M., Butler, R. J., Edwards, N. P., Milner, A.R. (2008): Pterosaur distribution in time and space: an atlas. Zitteliana B 28, 61-107.

Behrensmeyer, A.K. (1988): Vertebrate preservation in fluvial channels. Palaeogeography, Palaeoclimatology, Palaeoecology 63, 183-199. doi: 10.1016/0031-0182(88)90096-X.

Behrensmeyer, A.K. (1991): Terrestrial vertebrate accumulations. In: P.A. Allison, D.E.G. Briggs (eds.), Taphonomy - Releasing the Data Locked in the Fossil Record. Plenum Press, New York, pp. 291-335.

Berreteaga, A. (2008): Estudio estratigráfico, sedimentológico y paleontológico de los yacimientos con fósiles de vertebrados del Cretácico final de la Región Vasco-Cantábrica. Unpublished Doctoral Thesis, Universidad del País Vasco/Euskal Herriko Unibertsitatea (UPV/ EHU), Leioa, $410 \mathrm{p}$.

Berreteaga, A., Poyato-Ariza, F.J., Pereda-Suberbiola, X. (2011): A new actinopterygian fauna from the latest Cretaceous of Quintanilla lo Ojada (Burgos, Spain). Geodiversitas 33, 285-301. doi: 10.5252/ g2011n2a6.

Blain, H.-A., Canudo, J.I., Cuenca-Bescós, G., López-Martínez, N. (2010): Amphibians and squamate reptiles from the latest Maastrichtian (Upper Cretaceous) of Blasi 2 (Huesca, Spain). Cretaceous Research 31, 433-446. doi:10.1016/j.cretres.2010.06.001.

Brochu, C.A., Parris, D.C., Grandstaff, B.S., Denton, R.K., Jr., Gallagher, W.B. (2012): A new species of Borealosuchus (Crocodyliformes, Eusuchia) from the Late Cretaceous-Early Paleogene of New Jersey. Journal of Vertebrate Paleontology 32, 105-116. doi: 10.1080/02724634.2012.633585.

Buffetaut, E. (1999): Pterosauria from the Upper Cretaceous of Laño (Iberian Peninsula): a preliminary comparative study. Estudios del Museo de Ciencias Naturales de Álava 14 (Número especial 1), 289 294.

Buffetaut, E. (2005): Late Cretaceous vertebrates from the Saint-Chinian area (southern France): a review of previous research and an update of recent finds. Acta Palaeontologica Romaniae 5, 39-48.

Buffetaut, E. (2008): Late Cretaceous pterosaurs from France: a review. Zitteliana B 28, 249-55.

Buffetaut, E., Le Loeuff, J., Cavin, L., Duffaud, S., Gheerbrant, E., Laurent, Y., Martin, M., Rage, J.C., Tong, H., Vasse, D. (1997): Late Cretaceous non-marine vertebrates from southern France: a review of recent finds. Geobios 30 (supplement 1), 101-108. doi: 10.1016/ S0016-6995(97)80015-0.

Buffetaut, E., Pereda Suberbiola, X., Corral, J.C. (2006): A bird-like tibiotarsus from the Late Cretaceous of Laño (Iberian Peninsula). $A b$ stracts 54th Symposium of Vertebrate Palaeontology and Comparative Anatomy, Paris, pp. 4-5.

Buscalioni, A.D., Ortega, F., Vasse, D. (1997): New crocodiles (Eusuchia: Alligatoroidea) from the Upper Cretaceous of southern Europe. Comptes Rendus de l'Académie des Sciences Paris 325 (IIa), 525-530. doi: 10.1016/S1251-8050(97)89872-2.

Buscalioni, A.D., Ortega, F., Vasse, D. (1999): The Upper Cretaceous crocodilian assemblage from Laño (Northcentral Spain): implications in the knowledge of the finicretaceous European faunas. Estudios del Museo de Ciencias Naturales de Álava 14 (Número especial 1), 213-233.

Buscalioni, A.D., Ortega, F., Weishampel, D.B., Jianu, C.M. (2001): A revision of the Crocodyliform Allodaposuchus precedens from the 
Upper Cretaceous of the Hateg Basin, Romania. Its relevance in the phylogeny of Eusuchia. Journal of Vertebrate Paleontology 21, 7486. doi: 10.1671/0272-4634(2001)021[0074:AROTCA]2.0.CO;2.

Buscalioni A.D., Pérez-Moreno B.P., Sanz J.L. (2003): Pattern of biotic replacement in modern crocodiles during the Late Cretaceous. Coloquios de Paleontología volumen extraordinario 1, 77-93.

Buscalioni, A.D., Piras, P., Vullo, R., Signore, M., Barbera, C. (2011): Early Eusuchia Crocodylomorpha from the vertebrate-rich Plattenkalk of Pietraroia (Lower Albian, southern Apennines, Italy). Zoological Journal of the Linnean Society 163, 199-227. doi: 10.1111/j.10963642.2011.00718.x.227.

Cappetta, H., Corral, J.C. (1999): Upper Maastrichtian selachians from the Condado de Treviño (Basque-Cantabrian Region, Iberian Peninsula). Estudios del Museo de Ciencias Naturales de Álava 14 (Número especial 1), 339-372.

Cavin, L. (1999): Osteichthyes from the Upper Cretaceous of Laño (Iberian Peninsula). Estudios del Museo de Ciencias Naturales de Álava 14 (Número especial 1), 105-110.

Company, J., Ruiz-Omeñaca, J. I., Pereda Suberbiola, X. (1999): A longnecked pterosaur (Pterodactyloidea, Azhdarchidae) from the Upper Cretaceous of Valencia, Spain. Geologie en Mijnbouw 78, 319-333. doi: 10.1023/A:1003851316054.

Company, J., Pereda Suberbiola, X., Ruiz-Omeñaca, J.I. (2009): Nuevos restos fósiles del dinosaurio Lirainosaurus (Sauropoda, Titanosauria) en el Cretácico Superior (Campaniano-Maastrichtiano) de la Península Ibérica. Ameghiniana 46, 391-405.

Csiki-Sava, Z., Buffetaut, E., Ösi, A., Pereda Suberbiola, X., Brusatte, S.L. (2015): Island life in the Cretaceous - faunal composition, biogeography, evolution, and extinction of landliving vertebrates on the Late Cretaceous European archipelago. Zookeys 469, 1-161. doi: 10.3897/zookeys.469.8439

Delfino, M., Codrea, V., Folie, A., Dica, P., Godefroit, P., Smith, T. (2008): A complete skull of Allodaposuchus precedens Nopcsa, 1928 (Eusuchia) and a reassessment of the morphology of the taxon based on the Romanian remains. Journal of Vertebrate Paleontology 28, 111-122. doi: 10.1080/02724631003758318.

Díez Díaz, V. (2013): Revisión del dinosaurio saurópodo Lirainosaurus astibiae (Titanosauria) del Cretácico superior de la Península Ibérica: comparación con otros titanosaurios del suroeste de Europa. Hipótesis filogenética y paleobiogeográfica. Unpublished Doctoral Thesis, Universidad del País Vasco/Euskal Herriko Unibertsitatea (UPV/EHU), Bilbao, 306 p.

Díez Díaz, V., Pereda Suberbiola, X., Sanz, J.L. (2011): Braincase anatomy of the titanosaurian sauropod Lirainosaurus astibiae from the Late Cretaceous of the Iberian Peninsula. Acta Palaeontologica Polonica 56, 521-533. doi: 10.4202/app.2010.0043.

Díez Díaz, V., Pereda Suberbiola, X., Sanz, J.L. (2012): Juvenile and adult teeth of the titanosaurian dinosaur Lirainosaurus (Sauropoda) from the Late Cretaceous of Iberia. Geobios 45, 265-274. doi: 10.1016/j.geobios.2011.10.002.

Díez Díaz, V., Pereda Suberbiola, X., Sanz, J.L. (2013a): The axial skeleton of the titanosaur Lirainosaurus astibiae (Dinosauria: Sauropoda). Cretaceous Research 43, 145-160. doi: 10.1016/j.cretres.2013.03.002.

Díez Díaz, V., Pereda Suberbiola, X., Sanz, J.L. (2013b): Appendicular skeleton and dermal armour of the Late Cretaceous titanosaur Lirainosaurus astibiae (Dinosauria: Sauropoda) from Spain. Palaeontologia Electronica 16(2), 19A, 1-18.

Díez Díaz, V., Tortosa, T., Le Loeuff, J. (2013c): Sauropod diversity in the Late Cretaceous of southwestern Europa: The lessons of odontology. Annales de Paléontologie 99, 119-129. doi: 10.1016/j.annpal.2012.12.002.

Duffaud, S. (2000): Les faunes d'amphibiens du Crétacé supérieur à I'Oligocène inférieur en Europe: paléobiodiversité, évolution, mise en place. Unpublished Doctoral Thesis, Muséum National d'Histoire Naturelle, Paris, 2 vol., 221 p., 152 figs.

Duffaud, S., Rage, J.-C. (1999): Amphibians from the Upper Cretaceous of Laño (Basque Country, Spain). Estudios del Museo Ciencias Naturales de Álava 14 (Número especial 1), 111-120.

Elorza, J., Astibia, H., Murelaga, X., Pereda Suberbiola, X. (1999): Francolite as a diagenetic mineral in dinosaur and other Upper Cretaceous reptile bones (Laño, Iberian Peninsula): microstructural, petrological and geochemical features. Cretaceous Research 20, 169 187. doi: 10.1006/cres.1999.0144.

Fernández López, S. (2000): Temas de Tafonomía. Universidad Complutense de Madrid, Departamento de Paleontología, 167 p.

Floquet, M. (1991): La plate-forme nord-castillane au Crétacé supérieur (Espagne). Arrière-pays ibérique de la marge passive basco-cantabrique. Sédimentation et Vie. Mémoires Géologiques de l'Université de Dijon 14, 925 p.

Floquet, M. (1998): Outcrop cycle stratigraphy of shallow ramp deposits, the Late Cretaceous series of the Castilian Ramp (northern Spain). In: P.C.de Graciansky, J. Hardenbol, T. Jacquin, P.R. Vail (eds.), Mesozoic and Cenozoic Sequence Stratigraphy of European Basins. Society for Sedimentary Geology Special Publication 60, 343-361. doi: 10.2110/pec.98.02.0343.

Folie, A., Codrea, V. (2005): New lissamphibians and squamates from the Maastrichtian of Hateg Basin, Romania. Acta Palaeontologica Polonica 50, 57-71.

Forir, H. (1887): Contribution à l'étude du système crétacé de la Belgique. Mémoires I. Sur quelques poissons et crustacés nouveaux ou peu connus. Annales de la Société géologique de Belgique 14, 25-56.

Gaffney, E.S., Tong, H., Meylan, P.A. (2006): Evolution of the side-necked turtles: the families Bothremydidae, Euraxemydidae, and Araripemydidae. Bulletin of the American Museum of Natural History 300, 1-698. doi: 10.1206/0003-0090(2006)300[1:EOTSTT]2.0.CO;2.

Garcia, G., Pereda Suberbiola, X. (2003): A new species of Struthiosaurus (Dinosauria: Ankylosauria) from the Upper Cretaceous of Villeveyrac (southern France). Journal of Vertebrate Paleontology 23, 157-166. doi: 10.1671/0272-4634(2003)23[156:ANSOSD]2.0. CO;2 [and Correction, Journal of Vertebrate Paleontology 23, 985] doi: $10.1671 / 28$.

Garcia, G., Duffaud, S., Feist, M., Marandat, B., Tambareau, Y., Villatte, J., Sigé, B. (2000): La Neuve, gisement à plantes, invertébrés et vertébrés du Bégudien (Sénonien supérieur continental) du bassin d'Aix-en-Provence. Geodiversitas 22, 325-348.

Garcia G., Amico S., Fournier F., Thouand E., Valentin X. (2010): A new titanosaur genus (Dinosauria, Sauropoda) from the Late Cretaceous of southern France and its paleobiogeographical implications. Bulletin de la Société Géologique de France 181, 269-277. doi: 10.2113/ gssgfbull.181.3.269.

Gheerbrant, E., Astibia, H. (1994): Un nouveau mammifère du Maastrichtien de Laño (Pays Basque espagnol). Comptes Rendus de l'Académie des Sciences Paris 318 (IIa), 1125-1131.

Gheerbrant, E., Astibia, H. (1999): The Upper Cretaceous mammals from Laño (Spanish Basque Country). Estudios del Museo de Ciencias Naturales de Álava 14 (Número especial 1), 295-323.

Gheerbrant, E., Astibia, H. (2012): Addition to the Late Cretaceous Laño mammal faunule (Spain), and to the knowledge of European "Zhelestidae" (Lainodontinae nov.). Bulletin de la Sociéte Géologique de France 183, 537-546. doi: 10.2113/gssgfbull.183.6.537.

Gheerbrant, E., Rage, J.C. (2006): Paleobiogeography of Africa: How distinct from Gondwana and Laurasia? Palaeogeography, Palaeoclimatology, Palaeoecology 241, 224-246. doi: 10.1016/j.palaeo.2006.03.016.

Gómez-Alday, J.J. (1999): Stratigraphy and depositional environments of the Upper Cretaceous of the Laño quarry. Evidence of diapiric ac- 
tivity. Estudios del Museo de Ciencias Naturales de Álava 14 (Número especial 1), 29-35.

Grande, L. (2010): An empirical synthetic pattern study of gars (Lepisosteiformes) and closely related species, based mostly on skeletal anatomy. The resurrection of Holostei. American Society of Ichthyologists and Herpetologists, Special Publication 6. Copeia 10, supplementary issue 2A, 1-871. doi: 10.1643/0045-8511-11.1.bmi.

Joyce, W.G., Chapman, S.D., Moody, R.T.J., Walker, C.A. (2011): The skull of the solemydid turtle Helochelydra nopcsai from the Early Cretaceous of the Isle of Wight (UK) and a review of Solemydidae. Special Papers in Palaeontology 86, 75-97. doi: 10.1111/j.14754983.2011.01075.x.

Kielan-Jaworowska, Z., Cifelli, R.L., Luo, Z.-X. (2004): Mammals from the age of dinosaurs: origins, evolution, and structure. Columbia University Press, New York, $630 \mathrm{p}$.

LaDuke, T.C., Krause, D.W., Scanlon, J.D., Kley, N.J. (2010): A Late Cretaceous (Maastrichtian) snake assemblage from the Maevarano Formation, Mahajanga Basin, Madagascar. Journal of Vertebrate Paleontology 30, 109-138. doi: 10.1080/02724630903409188.

Lapparent de Broin, F. de, Murelaga, X. (1996): Une nouvelle faune de chéloniens dans le Crétacé supérieur européen. Comptes Rendus de l'Académie des Sciences Paris 323 (IIa), 729-735.

Lapparent de Broin, F. de, Murelaga, X. (1999): Turtles from the Upper Cretaceous of Laño (Iberian Peninsula). Estudios del Museo Ciencias Naturales de Álava 14 (Número especial 1), 135-211.

Lapparent de Broin, F. de, Murelaga Bereikua, X., Codrea, V. (2004): Presence of Dortokidae (Chelonii, Pleurodira) in the earliest Tertiary of the Jibou Formation, Romania: paleobiogeographical implications. Acta Palaeontologica Romaniae 4, 203-215.

Laurent, Y., Cavin, L., Bilotte, M. (1999): Découverte d'un gisement à vertébrés dans le Maastrichtien supérieur des Petites-Pyrénées. Comptes Rendus de l'Académie des Siences Paris 328 (IIa), 781-787. doi : 10.1016/S1251-8050(99)80171-2.

Laurent, Y., Le Loeuff, J., Bilotte, M., Buffetaut, E., Odin, G.S. (2001): Campanian-Maastrichtian continental-marine connection at the Aquitaine-Pyrennes-Provence area (S France). In: G.S. Odin (ed.), The Campanian-Maastricthian stage boundary, Chraracterisation at Tercis les bains (France) and correlations with Europe and other continents, Developments in Palaeontology and Stratigraphy, 19. Elsevier, Amsterdam, pp. 657-665.

Lécuyer, C., Bofey, C., Garcia, J.P., Grandjean, P., Barrat, J.-A., Floquet, M., Bardet, N., Pereda-Suberbiola, X. (2003): Stable isotope composition and rare earth element content of vertebrate remains from the Late Cretaceous of northern Spain (Laño): did the environmental record survive? Palaeogeography, Palaeoclimatology, Palaeoecology 193, 457-471. doi: 10.1016/S0031-0182(03)00261-X [and Corrigendum, Palaeogeography, Palaeoclimatology, Palaeoecology 196, 427-428]. doi: 10.1016/S0031-0182(03)00454-1.

Le Loeuff, J. (1991): The Campano-Maastrichtian vertebrate faunas from southern Europe and their relationships with other faunas in the world; palaeobiogeographical implications. Cretaceous Research 12, 93-114. doi: 10.1016/S0195-6671(05)80019-9.

Le Loeuff, J. (1992): Les vertébrés continentaux du Crétacé supérieur d'Europe: paléoécologie, biostratigraphie et paléobiogéographie. Unpublished Doctoral Thesis, Mémoires des Sciences de la Terre, Université Pierre and Marie Curie, Paris VI, 92/93, 273 p.

Le Loeuff J., Buffetaut E. (1991): Tarascosaurus salluvicus nov. gen., nov. sp., dinosaure théropode du Crétacé supérieur du sud de la France. Geobios 24, 585-594. doi: 10.1016/0016-6995(91)80022-R.

Leriche, M. (1938): Contribution à l'étude des poissons fossiles des pays riverains de la Méditerranée américaine (Vénézuéla, Trinité, Antilles, Mexique). Mémoires de la Société Paléontologique Suisse 61, 1-42.

Martin, J.E. (2007): New material of the Late Cretaceous globidontan Acynodon iberoccitanus (Crocodylia) from southern
France. Journal of Vertebrate Paleontology 27, 362-372. doi: 10.1671/0272-4634(2007)27[362:NMOTLC]2.0.CO;2.

Martin, J.E. (2010): Allodaposuchus Nopcsa, 1928 (Crocodylia, Eusuchia) from the Late Cretaceous of southern France and its relationships to Alligatoroidea. Journal of Vertebrate Paleontology 30, 756-767. doi: 10.1080/02724631003758318

Martin, J.E., Delfino, M. (2010): Recent advances in the comprehension of the biogeography of Cretaceous European eusuchians. Palaeogeography, Palaeoclimatology, Palaeoecology 293, 406-418. doi: 10.1016/j.palaeo.2009.10.021.

Narváez, I., Ortega, F. (2011): Eusuquios basales y aligatoroideos basales del Cretácico Superior europeo: estado de la cuestión. Viajando a Mundos Pretéritos, IX Encuentro de Jóvenes Investigadores en Paleontología, Morella, Castellón. Ayuntamiento de Morella, Morella, pp. 275-289.

Núnez-Betelu, K. (1999): Preliminary palynological assessment of the vertebrate-rich Laño beds: age and paleoenvironment. Estudios del Museo de Ciencias Naturales de Álava 14 (Número especial 1), $37-42$.

Ortega, F., Pérez-García, A. (2009): Cf. Lirainosaurus sp. (Dinosauria: Titanosauria) en el Cretácico Superior de Sacedón (Guadalajara). Geogaceta 46, 87-90.

Ortega, F., Sanz, J.L., Barroso-Barcenilla, F., Cambra-Moo, O., Escaso, F., García-Oliva, M., Marcos Fernández, F. (2008): El yacimiento de macrovertebrados fósiles del Cretácico Superior de "Lo Hueco" (Fuentes, Cuenca). Palaeontologica Nova SEPAZ 8, 119-131.

Ortega, F., Bardet, N., Barroso-Barcenilla, F., Callapez, P.M., CambraMoo, O., Daviero-Gómez, V., Díez Díaz, V., Domingo, L., Elvira, A., Escaso, F., García-Oliva, M., Gómez, B., Houssaye, A., Knoll, F., Marcos-Fernández, F., Martín, M., Mocho, P., Narváez, I., PérezGarcía, A., Peyrot, D., Segura, M., Serrano, H., Torices, A., Vidal, D., Sanz, J.L. (this volumen): The biota of the Late Cretaceous site of Lo Hueco (Cuenca, Spain). Journal of Iberian Geology.

Ösi, A., Weishampel, D.B., Jianu, C.-M. (2005): First evidence of azhdarchid pterosaurs from the Late Cretaceous of Hungary. Acta Paleontologica Polonica 50, 777-787.

Ösi, A., Apesteguía, S., Kowalewski, M. (2010): Non-avian theropod dinosaurs from the early Late Cretaceous of Central Europe. Cretaceous Research 31, 304-320. doi:10.1016/j.cretres.2010.01.001.

Ösi, A., Prondvai, E., Butler, R., Weishampel, D.B. (2012): Phylogeny, histology and inferred body size evolution in a new rhabdodontid dinosaur from the Late Cretaceous of Hungary. PLoS ONE 7(9), e44318. doi:10.1371/journal.pone.0044318.

Pereda Suberbiola, X. (1993a): Un dinosaure cuirassé (Ornithischia: Ankylosauria) dans le Crétacé supérieur de Laño (Bassin Basco-Cantabrique). Paleontologia i Evolució 26-27, 231-235.

Pereda Suberbiola, X. (1993b): Les dinosaures ankylosauriens d'Europe: systématique et évolution. Unpublished Doctoral Thesis, Mémoires des Sciences de la Terre, Université Pierre and Marie Curie, Paris VI, 9320, 300 p.

Pereda Suberbiola, X. (1999): Ankylosaurian dinosaur remains from the Upper Cretaceous of Laño (Iberian Peninsula). Estudios del Museo de Ciencias Naturales de Álava 14 (Número especial 1), 273-288.

Pereda Suberbiola, X. (2009): Biogeographical affinities of Late Cretaceous tetrapods of Europe: a reappraisal. Bulletin de la Société Géologique de France 180, 57-71. doi: 10.2113/gssgfbull.180.1.57.

Pereda Suberbiola X., Galton, P.M. (2009): Dwarf dinosaurs in the latest Cretaceous of Europe? In: P. Huerta, F. Torcida Fernández-Baldor (eds.), Actas IV Jornadas Internacionales sobre Paleontología de Dinosaurios y su Entorno, Salas de los Infantes, Burgos, pp. 263-272.

Pereda Suberbiola, X., Sanz, J.L. (1999): The ornithopod dinosaur Rhabdodon from the Upper Cretaceous of Laño (Iberian Peninsula). Estudios del Museo de Ciencias Naturales de Álava 14 (Número especial 1), 257-272. 
Pereda Suberbiola, X., Corral, J.C., García-Garmilla, F., Astibia, H. (1992): Tafonomía del yacimiento de vertebrados de Laño (Cretácico superior, Cuenca Vasco-Cantábrica): datos preliminares. Resúmenes VIII Jornadas de Paleontología, Sociedad Española de Paleontología, Barcelona, pp. 119-120.

Pereda Suberbiola, X., Astibia, H., Buffetaut, E. (1995): New remains of the armoured dinosaur Struthiosaurus from the Late Cretaceous of the Iberian Peninsula (Laño locality, Basque-Cantabric Basin). Bulletin de la Société géologique de France 166, 105-109.

Pereda Suberbiola X., Astibia H., Murelaga X., Elorza, J.J., Gómez-Alday, J.J. (2000): Taphonomy of the Late Cretaceous dinosaur-bearing beds of the Laño Quarry (Iberian Peninsula). Palaeogeography, Palaeoclimatolology, Palaeoecology 157, 247-275. doi: 10.1016/S00310182(99)00169-8

Pereda Suberbiola X., Ruiz-Omeñaca J.I., Company J. (2003): Los dinosaurios hadrosaurios del registro ibérico. Descripción de nuevo material del Cretácico superior de Laño (Condado de Treviño). In: F. Pérez Lorente (coord.), Dinosaurios y otro reptiles mesozoicos de España, Instituto de Estudios Riojanos (IER), Logroño. Ciencias de la Tierra 26, 375-388.

Pereda Suberbiola, X., Pérez-García, A., Corral, J.C., Murelaga, X., Martin, G., Larrañaga, J., Bardet, N., Berreteaga, A., Company, J. (in press): First dinosaur and turtle remains from the latest Cretaceous shallow marine deposits of Albaina (Laño quarry, Iberian Peninsula). Comptes Rendus Palevol.

Pérez-García, A. (2009): Historia evolutiva de las tortugas de la Península Ibérica. In: H. Dopazo, A. Navarro (eds.), Adaptación y Evolución. 150 años después del Origen de las especies. Sociedad Española de Biología Evolutiva (SESBE), Editorial Obrapropia, Valencia, pp. 425-431.

Pérez-García, A. (2012): Las tortugas mesozoicas de la Peninsula Ibérica. Unpublished Doctoral Thesis, Universidad Complutense de Madrid, Madrid, $415 \mathrm{p}$.

Pérez-García, A., Scheyer, T.M., Murelaga, X. (2012a): New interpretations of Dortoka vasconica Lapparent de Broin and Murelaga, a freshwater turtle with an unusual carapace. Cretaceous Research 36, 151-161. doi:10.1016/j.cretres.2012.03.006.

Pérez-García, A., Ortega, F., Murelaga, X. (2012b): A new genus of Bothremydidae (Chelonii, Pleurodira) in the Cretaceous of Southwestern Europe. Geobios 45, 219-229. doi:10.1016/j.geobios.2011.03.001.

Pérez-García, A., Ortega, F., Murelaga, X. (2013): Two synchronic and sympatric Bothremydidae taxa (Chelonii, Panpleurodira) in the Late Cretaceous site of "Lo Hueco" (Cuenca, Spain). In: Brinkman, D.B., Holroyd, P.A., Gardner, J.D. (eds.), Morphology and Evolution of Turtles, Proceedings of the Gaffney Turtle Symposium (2009) in Honor of Eugene S. Gaffney. Vertebrate Paleobiology and Paleoanthropology Series, Springer, Dordrecht, pp. 251-259.

Pol, D., Turner, A.H., Norell, M.A. (2009): Morphology of the Late Cretaceous crocodylomorph Shamosuchus djadochataensis and a discussion of neosuchian phylogeny as related to the origin of Eusuchia. Bulletin of the American Museum of Natural History 324, 1-103.

Poyato-Ariza, F.J., Martín-Abad, H. (2013): History of two lineages: comparative analysis of the fossil record in Amiiformes and Pycnodontiformes (Osteichthyes, Actinopterygii). Spanish Journal of Palaeontology 28, 79-90.

Poyato-Ariza, F.J., Wenz, S. (2002): A new insight into pycnodontiform fishes. Geodiversitas 24, 139-248.

Poyato-Ariza, F.J., Wenz, S. (2005): Akromystax tilmachiton gen. et sp. nov., a new pycnodontid fish from the Lebanese Late Cretaceous of Haqel and En Nammoura. Journal of Vertebrate Palaeontology 25, 27-45. doi: 10.1671/0272-4634(2005)025[0027:ATGESN]2.0.CO;2.

Poyato-Ariza, F.J., Fielitz, C., Wenz, S. (1999): Marine actinopterygian fauna from the Upper Cretaceous of Albaina (Laño quarry, Northern Spain). Estudios del Museo Ciencias Naturales de Álava 14 (Número especial 1), 325-338.

Prieto-Márquez, A., Dalla Vecchia, F.M., Gaete, R., Galobart, A. (2013): Diversity, relationships, and biogeography of the lambeosaurine dinosaurs from the European archipelago, with description of the new aralosaurin Canardia garonnensis. PLOS ONE 8(7), e69835. doi:10.1371/journal.pone.0069835.

Puértolas-Pascual, E., Canudo, J.I., Moreno-Azanza, M. (2014): The eusuchian crocodylomorph Allodaposuchus subjuniperus sp. nov., a new species from the latest Cretaceous (upper Maastrichtian) of Spain. Historical Biology 26, 91-109. doi: 10.1080/08912963.2012.763034.

Rage, J.-C. (1996): Les Madtsoiidae (Reptilia, Serpentes) du Crétacé supérieur d'Europe: témoins gondwaniens d'une dispersion transtéthysienne. Comptes Rendus de l'Académie des Sciences Paris 322 (IIa), 603-608.

Rage, J.-C. (1999): Squamates (Reptilia) from the Upper Cretaceous of Laño (Basque Country, Spain). Estudios del Museo Ciencias Naturales de Álava 14 (Número especial 1), 121-133.

Rage, J.-C. (2002): The continental Late Cretaceous of Europe: toward a beter understanding. Comptes Rendus Palevol 1, 257-258. doi: 10.1016/S1631-0683(02)00038-6.

Rage, J.-C. (2013): Mesozoic and Cenozoic squamates of Europe. Palaeobiodiversity and Palaeoenvironments 93, 517-534. doi: 10.1007/ s12549-013-0124-x.

Russell, D.A. (1993): The role of Central Asia in dinosaurian biogeography. Canadian Journal of Earth Sciences 30, 2002-2012. doi: 10.1139/e93-176.

Sanz, J.L. (1986): Nouveaux gisements de dinosaures dans le Crétacé espagnol. In: Les Dinosaures de la China à la France. Colloque International de Paléontologie. Muséum de Toulouse, Toulouse, pp. 81-88.

Sanz, J.L., Powell, J.E., Le Loeuff, J., Martinez, R., Pereda Suberbiola, X. (1999): Sauropod remains from the Upper Cretaceous of Laño (Northcentral Spain). Titanosaur phylogenetic relationships. Estudios del Museo de Ciencias Naturales de Álava 14 (Número especial 1), 235-255.

Scheyer, T., Pérez-García, A., Murelaga, X. (2015): Shell bone histology of solemydid turtles (stem Testudines): palaeoecological implications. Organisms Diversity and Evolution 15, 199-212. doi: 10.1007/ s13127-014-0188-0.

Thies, D. (1989): Lepidotes gloriae, sp. nov. (Actinopterygii: Semionotiformes) from the Late Jurassic of Cuba. Journal of Vertebrate Paleontology 9, 18-40. doi: 10.1080/02724634.1989.10011736.

Thompson, R.S., Parish, J.C., Maidment, S.C.R. Barrett, P.M. (2012): Phylogeny of the ankylosaurian dinosaurs (Ornithischia: Thyreophora). Journal of Systematic Palaeontology 10, 301-312. doi: 0.1080/14772019.2011.569091.

Torices, A. (2007): Los dinosaurios terópodos del Cretácico superior de la Cuenca surpirenaica. Unpublished Doctoral Thesis, Universidad Complutense de Madrid, Madrid, 409 p.

Torices, A., Currie, P.J., Canudo, J.I., Pereda Suberbiola, X. (in press): Theropod dinosaurs from the Upper Cretaceous of the South-Pyrenean Basin. Acta Palaeontologica Polonica (online). doi: 10.4202/ app.2012.0121.

Vasile, V., Csiki-Sava, Z., Venczel, M. (2013): A new madtsoiid snake from the Upper Cretaceous of the Haţeg Basin, western Romania. Journal of Vertebrate Paleontology 33, 1100-1119. doi: 10.1080/02724634.2013.764882.

Vasse, D. (1995): Ischyrochampsa meridionalis n.g. n. sp., un crocodilien d'affinité gondwanienne dans le Crétacé supérieur du Sud de la France. Neues Jahrbuch für Geologie und Paläontologie Monatshefte 8, 501-512.

Vincent, P., Bardet, N., Pereda Suberbiola, X., Bouya, B., Amaghzaz, M., Meslouh, S. (2011): Zarafasaura oceanis, a new elasmosaurid (Reptilia: Sauropterygia) from the Maastrichtian Phosphates of Morocco and the palaeobiogeography of latest Cretaceous plesiosaurs. 
Gondwana Research 19, 1062-1073. doi: 10.1016/j.gr.2010.10.005.

Vremir, M., Kellner, A.W.A., Naish, D., Dyke, G.J. (2013): A new azhdarchid pterosaur from the Late Cretaceous of the Transylvanian Basin, Romania: Implications for azhdarchid diversity and distribution. PLoS ONE 8(1), e54268. doi:10.1371/journal.pone.0054268.

Weishampel, D.B., Jianu, C.-M., Csiki, Z., Norman, D.B. (2003): Osteology and phylogeny of Zalmoxes (n.g.), an unusual euornithopod dinosaur from the latest Cretaceous of Romania. Journal of Systematic Palaeontology 1, 65-123.

Weishampel D.B., Csiki Z., Benton M.J., Grigorescu D., Codrea V. (2010): Palaeobiogeographic relationships of the Hațeg biota - Between isolation and innovation. Palaeogeography, Palaeoclimatolo- gy, Palaeoecology 293, 419-437. doi:10.1016/j.palaeo.2010.03.024.

Wible, J.R., Rougier, G.W., Novacek, M.J., Asher, R.J. (2009): The eutherian mammal Maelestes gobiensis from the Late Cretaceous of Mongolia and the phylogeny of Cretaceous Eutheria. Bulletin of the American Museum of Natural History 327, 1-123. doi: 10.1206/623.1.

Wiley, E.O. (1976): The phylogeny and biogeography of fossil and recent gars (Actinopterygii: Lepisosteidae). Miscellaneous Publications of the University of Kansas Museum Natural History 64, 1-111.

Wuttke, M., Přikryl, T., Ratnikov V.Y., Dvořák, Z., Roček, Z. (2012): Generic diversity and distributional dynamics of the Palaeobatrachidae (Amphibia: Anura). Palaeobiodiversity and Palaeoenvironments 92, 367-395. doi: 10.1007/s12549-012-0071-y. 